\title{
GDP PER CAPITA VERSUS MEDIAN HOUSEHOLD INCOME: WHAT GIVES RISE TO THE DIVERGENCE OVER TIME AND HOW DOES THIS VARY ACROSS OECD COUNTRIES?
}

\author{
BY BRIAN NOLAN**, MAX ROSER AND STEFAN THEWISSEN ${ }^{1}$ \\ Institute for New Economic Thinking and Department of Social Policy and \\ Intervention, University of Oxford
}

Divergence between the evolution of GDP per capita and the income of a 'typical' household as measured in household surveys is giving rise to a range of serious concerns, especially in the USA. This paper investigates the extent of that divergence and the factors that contribute to it across 27 OECD countries, using data from OECD National Accounts and the Luxembourg Income Study. While GDP per capita has risen faster than median household income in most of these countries over the period these data cover, the size of that divergence varied very substantially, with the USA a clear outlier. The paper distinguishes a number of factors contributing to such a divergence, and finds wide variation across countries in the impact of the various factors. Further, both the extent of that divergence and the role of the various contributory factors vary widely over time for most of the countries studied. These findings have serious implications for the monitoring and assessment of changes in household incomes and living standards over time.

JEL codes: D31, D60, E01

Keywords: Economic growth, inequality, household incomes

\footnotetext{
* Correspondence to: Brian Nolan, INET and Department of Social Policy, University of Oxford, brian.nolan@spi.ox.ac.uk

${ }^{1}$ We are grateful for vey helpful comments from Facundo Alvaredo (Paris School of Economics), Tony Atkinson (Nuffield), two anonymous referees, and participants at seminars and conference presentations including APPAM, LSE, 2016, SASE, Berkeley 2016, and ECINEQ, New York, 2017.
} 


\section{INTRODUCTION}

The evolution of GDP per head is widely taken to be the central indicator of a country's economic performance and success in improving living standards over time (see e.g. Coyle, 2014; Gordon, 2016; Feldstein, 2017). This remains the case despite increasing recognition of its limitations in those terms, as brought out comprehensively in the Stiglitz-Sen-Fitoussi Report (2009), and on-going efforts to address those limitations by national statistics offices and the UN, OECD and EU. There is increasing awareness that the evolution of average income at the national level as measured in the national accounts may fail to capture the experience in living standards of the 'typical' household. It has therefore been proposed that median household income, 'equivalised' to take differences in household size into account, should be used as a key indicator of changes in living standards (Aaberge and Atkinson, 2013; Boarini et al., 2015; Thewissen et al., 2015; Nolan et al., 2016).

Incomes for the typical household, however, might not grow in tandem with GDP. To drive home from the outset that this divergence really matters, one can point to the experience of the USA. Figure 1 (using definitions and sources to be described below) illustrates the yawning gap between cumulative growth in GDP per capita and in median equivalised household income (each in real terms) seen there in recent years. The USA may not be representative, however, either in the extent of this divergence or the mix of factors producing it; indeed, this paper will demonstrate the very substantial heterogeneity across rich countries, and indeed over different timeperiods, in that regard. 


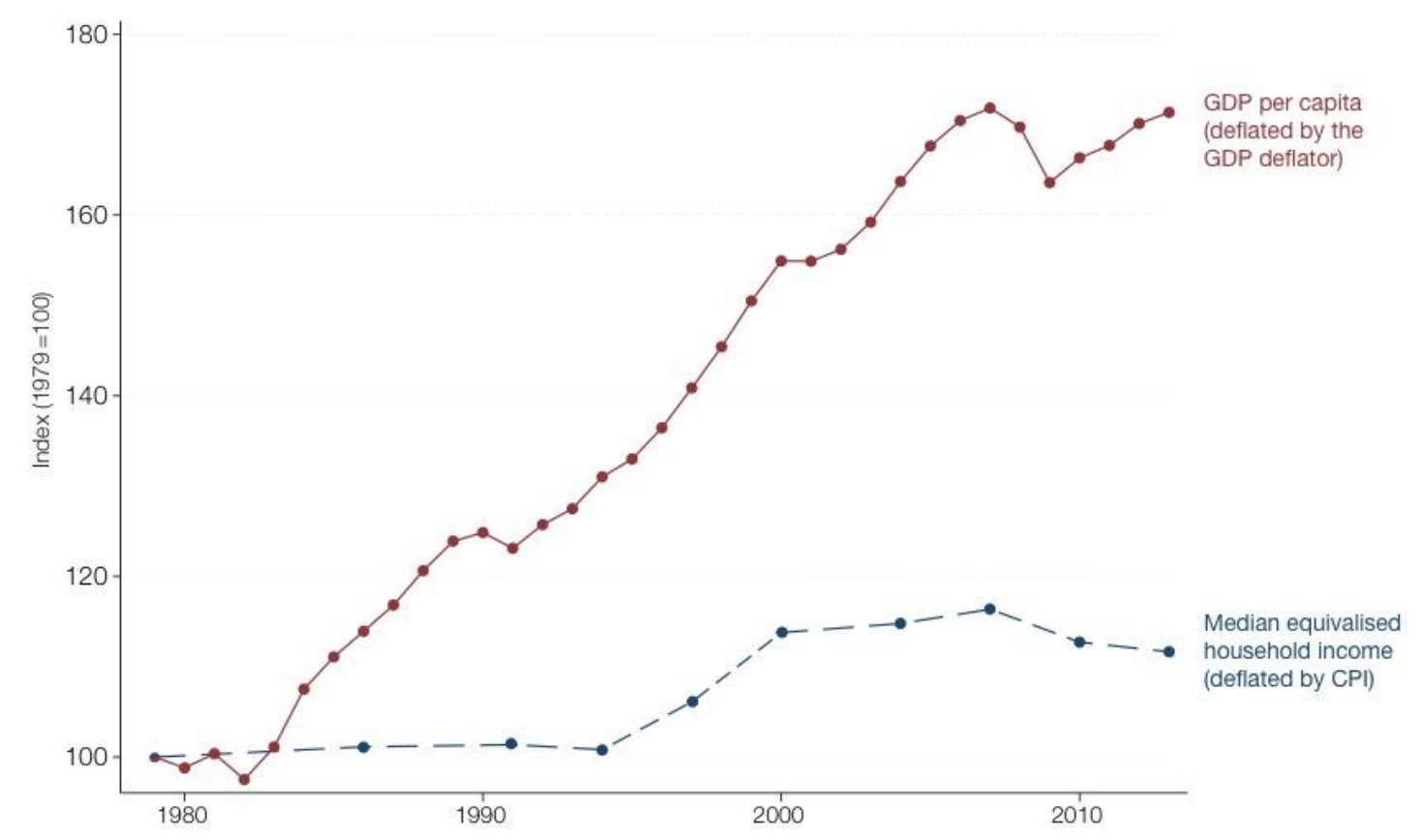

Figure 1: Growth in GDP per capita and median household equivalised income, USA from 1979

Two reasons why the typical household might not benefit from economic growth have featured prominently in the academic debate. First, GDP per capita is produced in a national accounts framework whereas median household income is based on household surveys, and a common picture of how income is evolving in aggregate may not emerge because of mismeasurement or differences in income definitions. Organisations including the OECD and EU are devoting considerable analytical effort to explore an internationally comparable methodology to produce distributional income measures that are consistent with national accounts concepts and totals (Fesseau and Moronetti, 2013; Fessau et al., 2013; OECD, 2013; 2015a; European Commission, 2014; Causa et al., 2015; Ribarsky et al., 2016). Empirical studies on this matter tend to be comparative, showing that mean per capita income from national accounts and household surveys can diverge substantially (e.g., Smeeding and Weinberg, 2001; Bhalla, 2002; Deaton, 2005; Törmälehto, 2011; Endeweld and Alkemade, 2014; Atkinson et al., 2015; Pinkovskiy and Sala-i-Martin, 2016). Academic researchers are also actively engaged in developing Distributional National Accounts (Piketty et al., 2016).

The second reason attracting substantial attention is growing income inequality: if most of the increase in national income goes to the top of the 
distribution, the median will show little increase. Here, empirical studies in general are country cases, mostly on the USA (see e.g. Economic Report of the President, 2015; Fixler and Jaditz, 2002; Fixler and Johnson, 2014, Jorgenson and Slesnick, 2014; Fixler et al., 2015; see also Pessao and Van Reenen, 2013, on the UK).

This paper aims to provide a better understanding of what gives rise to the divergence between GDP and median household income growth over time, and how that varies across countries and over time. Compared to existing comparative studies, our analysis incorporates three other factors that may contribute at least as much as the two factors that attracted most attention - inequality and the divergence between national accounts and household surveys - namely differences in the price deflators employed, the difference between GDP and gross national income, and changing household size. By measuring the extent of the overall divergence and decomposing it to show the impact of these distinct contributory factors, we also bring out their substantive importance in properly assessing how living standards are evolving. Combining data from the Luxembourg Income Study and the OECD National Accounts, we employ a common analytical framework and bring out the substantial heterogeneity across the rich countries over recent decades both in terms of size of the divergence as well as the factors contributing to it.

Keeping in mind the substantial variation across countries and time, our findings are the following. We show that on average prices went up faster for consumers than for producers. The GDP-GNI distinction is important for only a few countries known to have large net factor outflows. A particular important factor leading equivalised income to lag behind per capita GDP is the shrinking household size in most countries, which implies smaller economies of scale in consumption of households. This often neglected factor is the most consistent in its impact across countries over time. Increasing inequality, measured as the divergence between mean and median household income, does not seem to be particularly important in explaining the divergence. We show that the Gini coefficient and average household size can almost fully explain the divergence between mean per capita and median equivalised household income. We explore the gap between income as measured in the national accounts versus household surveys in more depth, using regression analysis and detailed national accounts information.

The data and analytic framework we employ are discussed in Section 2. Section 3 shows how GDP per capita and median household income evolved over 
time across countries, and applies that analytic framework to decompose the divergence between them. The central factors contributing to that divergence are then examined in some depth: Section 4 deals with differences in price deflators and between national output and income concepts in the national accounts, Section 5 looks at the role of differences between the national accounts and household surveys, and Section 6 focuses on the role of changes in household size and in income inequality. Section 7 highlights the central messages from this comparative analysis across the OECD, and illustrates them for 6 large OECD economies Section 8 then examines how the extent and nature of the GDP-median income divergence varies over time within countries, distinguishing different sub-periods. Finally, Section 9 brings together the main conclusions and discusses their implications.

\section{DATA AND ANALYTIC FRAMEWORK}

We begin our analysis by introducing our framework and data to explain the divergence between GDP per capita and median household income, as well as its variation across countries and over tie. We postpone discussing the economic significance and possible reasons for the divergence in more detail to Sections 3-5.

With growth over time being the central focus, all variables in our analysis are expressed as compound annual growth rates (CAGRs). ${ }^{2}$ Figure 2 provides a framework for investigating the different factors that may contribute to the divergence between growth in GDP per capita on the one hand and median equivalised household income on the other. The figure sets out in its left-hand-side column a number of 'intermediate' variables that will serve to make the linkage between GDP per capita and median income; the second column identifies the underlying factors these represent or capture.

${ }^{2}$ The CAGR for variable $x$ over $n$ periods at time $t$ is calculated as

$$
\text { CAGR } x_{t}=\left(\frac{x_{t+n}}{x_{t}}\right)^{\frac{1}{n}}-1
$$




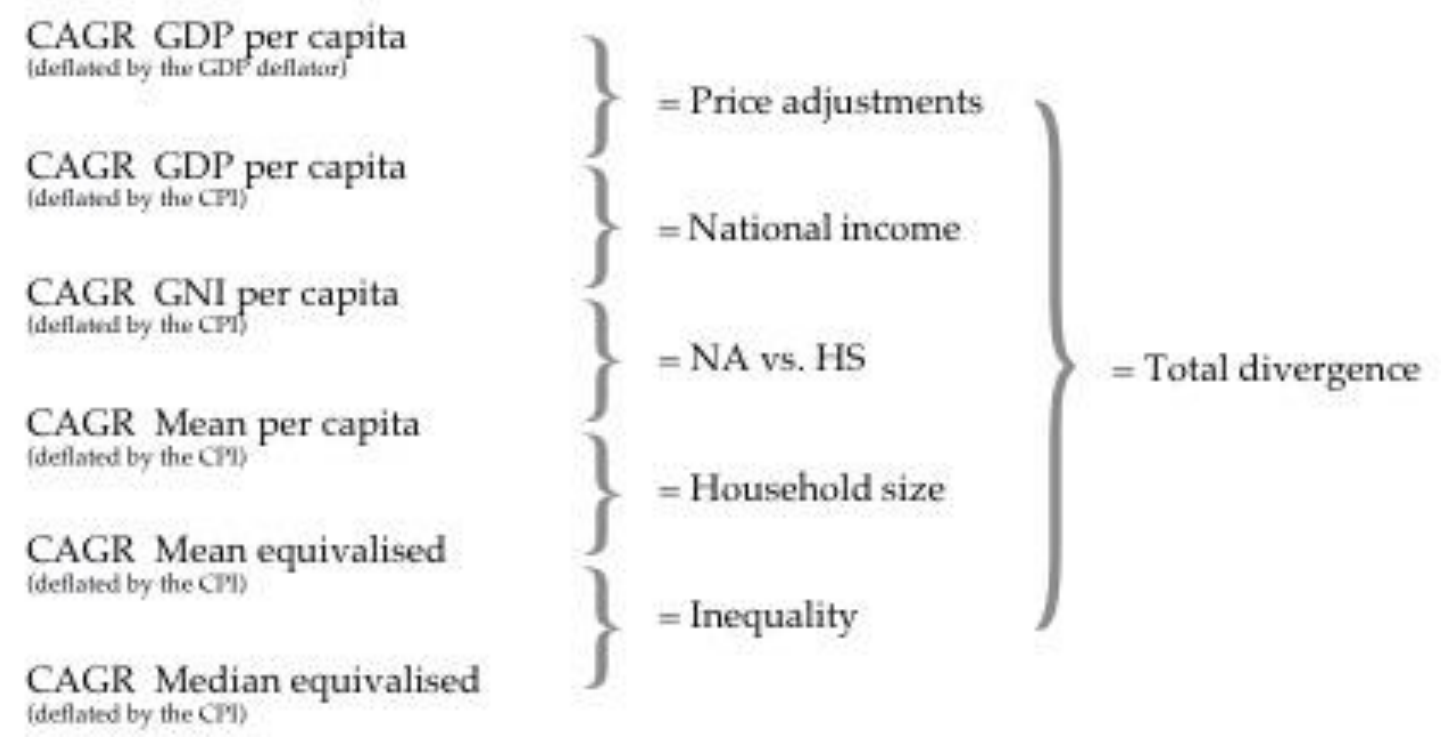

Figure 2: Accounting for the divergence between the growth of GDP per capita and median equivalised household income

\subsection{Price adjustments}

The first of the potential factors driving the divergence is the difference in price deflators employed to arrive at 'real' changes, with GDP per capita corrected using the GDP deflator whereas median household income is deflated using the CPI. We look at the impact of this difference by comparing GDP per capita deflated by the implicit GDP deflator with GDP per capita deflated using the CPI.

\subsection{GDP versus GNI}

The second factor to incorporate into the analysis is the fact that GDP measures the economic output of the country in question, whereas household surveys capture income flows to resident households including income from other countries and excluding income accruing externally. In national accounts terms, gross national income (GNI), which adjusts GDP for net factor income flows from abroad, is more closely aligned to the geographical coverage of household surveys. Comparing GDP and GNI per capita (with a common deflator, continuing here with the CPI) allows the impact of this factor to be assessed.

\subsection{National income versus mean income in household surveys}

The third factor we look at in our main analysis is the difference between GNI per capita as measured in the national accounts and mean income per head as captured in 
household surveys. These two income measures might diverge, mostly because of conceptual differences in income and the extent to which the sources are able to capture income from different sources that they aim to cover.

We look in our main analysis at the overall contribution of the difference between GNI and average household survey income per head over the longest period we can cover for each country. Data distinguishing the household sector in the national accounts are only available on a comparative basis for more recent years (often the mid-1990s) for many of the countries we are studying; we employ those data in Section 5 below to investigate the different elements underpinning this GNIsurvey income difference.

\subsection{Household size}

The fourth factor to be taken into account in our main analysis is the fact that income expressed in per capita terms may diverge from equivalised income - which is calculated by dividing income by the number of 'equivalent adults' rather than simply by the number of persons. This procedure aims to take into account that there are economies of scale in living together (see for example Atkinson et al., 1995. 2015; Peichl et al., 2012; Ferreira et al., 2015). We use the square root scale widely employed in comparative analysis of poverty and inequality, where the number of 'equivalent adults' is derived as the square root of the number of persons living in the household. ${ }^{3}$ Equivalised income will then diverge from income per capita over time if household size is changing: where it is declining, that serves to reduce the economies of scale from living together and equivalised income will lag behind income per head. We will compare the growth in mean income per capita in the household surveys with equivalised income in those surveys, to distinguish the impact this is having across different countries over time.

\subsection{Mean versus median income and the role of inequality}

The fifth and final factor to be incorporated into our analysis is that the change in mean income may well diverge from that in median income over time. This is likely to occur when the rate of income growth is not proportional across the distribution. The evolution of the gap between the mean and the median can itself be seen as a way

\footnotetext{
${ }^{3}$ Other commonly-used equivalence scales such as the modified OECD scale distinguish children from adults, but this is not always possible in the LIS data.
} 
to capture changes in the distribution of income - something we will come back to in our analysis. Comparing the growth in mean versus median equivalised income in the surveys allows us to assess the contribution this much-remarked on phenomenon makes to the overall divergence between GDP per capita and median equivalised household income.

\subsection{Order of the decomposition}

The order of the decomposition set out in this framework is to some degree arbitrary. In particular, while we look first at the differences in price deflators and from that point on employ the CPI, one could end rather than begin with that step. Similarly, we look at the mean/median gap and then at per capita versus equivalised income, whereas one could reverse that order. We will therefore empirically assess whether this ordering affects the findings.

\subsection{Data}

The data we employ on national accounts aggregates such as GDP and GNI, the GDP deflator, and the income of the household sector (in national accounts terms) and its components are taken from the OECD National Accounts. Data on the Consumer Price Index (CPI), Purchasing Power Parities (PPPs) and population are also taken from the relevant OECD databases. We derive on that basis GDP and GNI per capita expressed in real terms, deflated with either the GDP deflator or the CPI, which will be central to our main analysis.

On mean and median household income, we draw on the Luxembourg Income Study (LIS) database. This brings together micro data on income from household surveys, standardised insofar as possible across countries over time. ${ }^{4}$ The income definition employed is annual cash and near-cash money income from earnings, selfemployment, capital income, and taxes and transfers, summed at the household level. ${ }^{5}$ As well as income per capita, we derive measures of equivalised household income using the square root equivalence scale. The income measures to be used take the household as the income sharing unit but the individual as the unit of analysis - so

\footnotetext{
${ }^{4}$ For examples of its use see e.g., Atkinson et al. (1995); Gornick and Jannti (2013); for reviews of its quality see Ravallion (2015); Ferreira et al. (2015).

${ }^{5}$ In using data from LIS we set negative disposable household incomes to zero but retain all households with zero disposable income, rather than dropping negatives or zero incomes as is sometimes the practice, and we do not apply top and bottom coding.
} 
each person is attributed the income (per capita or equivalised) of their household. Household size and the Gini summary inequality measure are also derived from the LIS data and employed in our analysis.

Our country and year coverage is defined by the availability of the LIS micro data. We focus on 27 higher-income OECD countries, omitting middle-income OECD members Chile, Mexico, and Turkey as well as other middle-income countries such as South Africa which are in LIS. We begin our analysis around 1980 where possible (LIS has few observations before that), but for many countries data is available only from the mid-1980s, 1990, or even later. ${ }^{6}$ For the analysis using micro data, we are restricted by the LIS 'wave' structure whereby data is mostly included only at approximately five-year intervals for each country - in total, we make use of 153 observations.

\section{DECOMPOSING THE GDP-MEDIAN INCOME DIVERGENCE: THE RESULTS}

We now proceed to examine and decompose the divergence between GDP per capita and median household income using the longest available period for each country. We begin by looking at the extent to which the growth rate of GDP per capita (deflated by the GDP deflator) diverges from the increase in median equivalised household income (deflated using the CPI). Figure 3 plots the evolution of each of these in terms of the average annual growth rate. It also shows the extent of the divergence between them, with countries ranked by that divergence.

\footnotetext{
${ }^{6}$ We have dropped a small number of observations in LIS where breaks in series have given rise to substantial changes in definitions or coverage, based on information provided about the underling data sources and patterns in the data, namely Austria 1987 and 1995, Germany 1981, 1983, Netherlands 1983, 1987, 1990 and Switzerland 1982, 1992. We also do not use Israel 1979 or Poland 1986 because comparable price adjustment information is not available.
} 


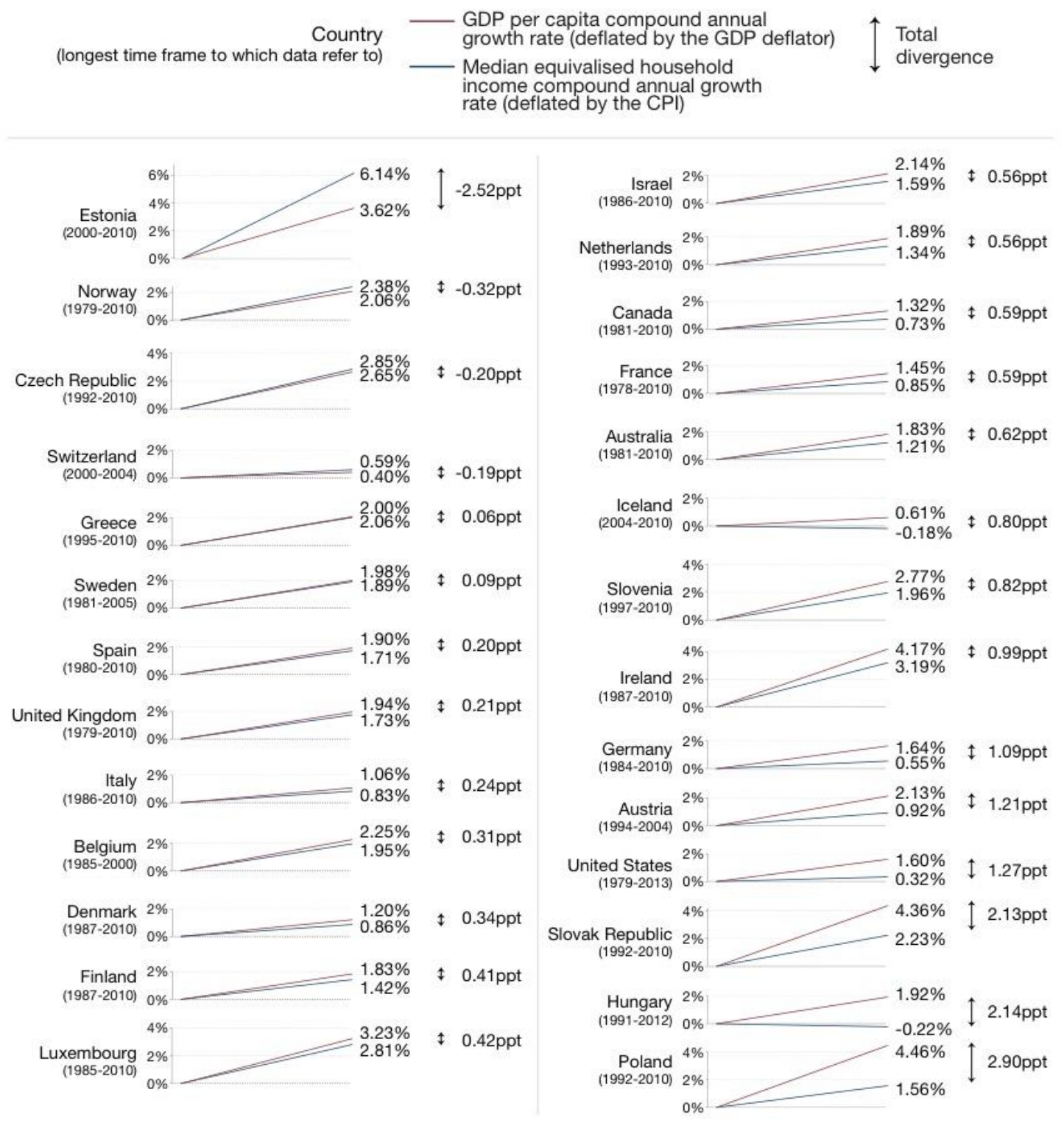

Figure 3: Country by country comparison of GDP per capita and equivalised household income growth over the longest time period available

We see that GDP per capita rose faster than median income in 23 out of the 27 countries - the exceptions being Czech Republic, Estonia, Norway, and Switzerland. This is in line with the concern outlined earlier that the growth of GDP per capita is often larger than the increase in real income experienced by 'typical' households. We also see from Figure 3 that the size of the divergence varies substantially across countries. The USA, where this has been most discussed, is among the countries where the divergence is greatest - though it is even wider for three transition countries, namely the Slovak Republic, Hungary and Poland, where the gap is over 2 percentage points per year on average. For the majority of countries the gap is 0.6 
percentage points or less. This is still substantial when cumulated over a significant period, but less striking than the USA, which is a clear outlier in this respect.

The second point to note about the US experience is that the annual average increase in the median over the long period from 1979 is very modest, at only $0.32 \%$. This marks it out as among the lowest in our set of countries, with only Hungary and Iceland seeing lower (in fact negative) growth in the median. In the case of Iceland this relates to the much shorter period available in LIS from 2004-2010, dominated by the Great Recession and Iceland's financial crash. The other countries seeing the median lag behind GDP per capita nonetheless saw some growth in the former, indeed countries such as Ireland, Poland and the Slovak Republic with a particularly large divergence between the two still saw relatively strong median income growth. So the USA is quite distinctive in its combination of a striking GDP-median divergence and very little growth in the median.

We now implement the analytical framework outlined in the previous section. The key figures are presented in Table 1, which proceeds through the steps of the analysis presented in Figure 2 for each of the countries we are covering over the longest time span for which we have data per country. Column (1) shows the average annual growth rate in GDP per capita and column (6) shows the corresponding average for median equivalised household income, deflated by the GDP deflator and CPI respectively; column (7) shows the difference between the two measures. Columns (2-5) present the annual average change in the 'intermediate variables' that will allow us to decompose the overall divergence, and we now discuss these in turn.

Table 2 presents the decomposition: it first shows in columns (1-3) once again the average annual growth in our two central variables of interest and the divergence between them. It then shows for each of the factors we have distinguished how much they contribute to the total divergence in percentage point terms (columns 4-8) and then the percentage of the total divergence attributable to each factor (columns 9-13). In interpreting these figures it is important to highlight that the percentage contributions in columns (9-13) can be misleading if taken on their own, since the underlying divergence being accounted for is so different and sometimes very small.

An overarching conclusion can first be drawn from Table 2: not only does the extent of the divergence vary widely across countries, as emphasized earlier, but so does the mix of factors contributing to produce it. This underpins the second point to be highlighted: the US experience, where the divergence itself is very wide and where 
differences between the price deflators, between national accounts and household survey per capita means, between per capita and equivalised income, and between the mean and the median all make substantial contributions to accounting for that divergence, is far from typical.

Having set out these results, we now look in more detail the various factors we have identified, to bring out the extent and nature of the variation in their contributions to the divergence we are aiming to explain. We focus in the next section on two that can be examined via the national accounts: the role of differences between price deflators and between national output and national income. 
Table 1: Decomposing the divergence over the longest available period for each country

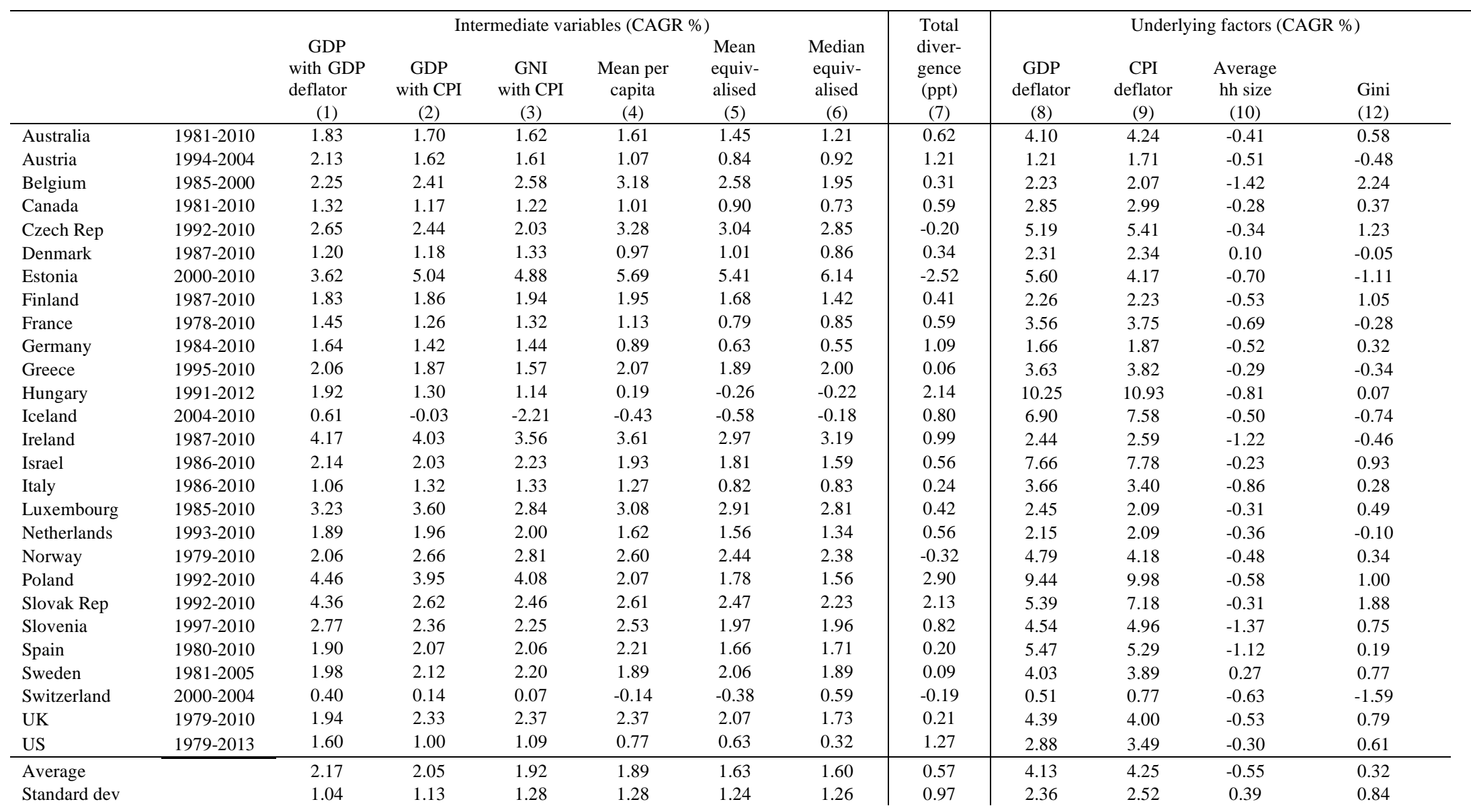


Table 2: Decomposing the GDP per capita-median household income divergence

\begin{tabular}{|c|c|c|c|c|c|c|c|c|c|c|c|c|c|c|}
\hline & & \multicolumn{2}{|c|}{ (A) $\mathrm{CAGR} \%$} & \multirow{2}{*}{$\begin{array}{c}\text { Total } \\
\text { divergence } \\
\text { (ppt) } \\
\text { (3) }\end{array}$} & \multicolumn{5}{|c|}{ (B) ppt contribution } & \multicolumn{5}{|c|}{ (C) $\%$ contribution } \\
\hline & & $\begin{array}{l}\text { GDP } \\
\text { (1) }\end{array}$ & $\begin{array}{l}\text { Median } \\
\text { equiv } \\
\text { (2) }\end{array}$ & & $\begin{array}{l}\text { Prices } \\
\text { (4) }\end{array}$ & $\begin{array}{l}\text { National } \\
\text { income } \\
(5)\end{array}$ & $\begin{array}{l}\text { NA vs } \\
\text { HS } \\
(6)\end{array}$ & $\begin{array}{c}\text { House- } \\
\text { hold size } \\
\text { (7) }\end{array}$ & $\begin{array}{c}\text { Inequality } \\
(8)\end{array}$ & $\begin{array}{l}\text { Prices } \\
\text { (9) }\end{array}$ & $\begin{array}{c}\text { National } \\
\text { income } \\
(10)\end{array}$ & $\begin{array}{l}\text { NA vs } \\
\text { HS } \\
(11)\end{array}$ & $\begin{array}{l}\text { House- } \\
\text { hold size } \\
\text { (12) }\end{array}$ & $\begin{array}{c}\text { Inequality } \\
\text { (13) }\end{array}$ \\
\hline Australia & 1981-2010 & 1.83 & 1.21 & 0.62 & 0.13 & 0.08 & 0.01 & 0.16 & 0.24 & 21 & 14 & 1 & 26 & 38 \\
\hline Austria & 1994-2004 & 2.13 & 0.92 & 1.21 & 0.50 & 0.02 & 0.54 & 0.23 & -0.08 & 42 & 2 & 45 & 19 & -7 \\
\hline Belgium & $1985-2000$ & 2.25 & 1.95 & 0.31 & -0.16 & -0.17 & -0.60 & 0.60 & 0.63 & -52 & -54 & -196 & 197 & 205 \\
\hline Canada & $1981-2010$ & 1.32 & 0.73 & 0.59 & 0.14 & -0.05 & 0.22 & 0.11 & 0.17 & 24 & -9 & 37 & 18 & 29 \\
\hline Czech Rep & $1992-2010$ & 2.65 & 2.85 & -0.20 & 0.22 & 0.41 & -1.25 & 0.23 & 0.19 & -110 & -210 & 637 & -118 & -99 \\
\hline Denmark & $1987-2010$ & 1.20 & 0.86 & 0.34 & 0.02 & -0.15 & 0.36 & -0.03 & 0.14 & 6 & -45 & 105 & -9 & 43 \\
\hline Estonia & $2000-2010$ & 3.62 & 6.14 & -2.52 & -1.42 & 0.16 & -0.81 & 0.28 & -0.73 & 56 & -6 & 32 & -11 & 29 \\
\hline France & $1978-2010$ & 1.45 & 0.85 & 0.59 & 0.19 & -0.05 & 0.18 & 0.34 & -0.06 & 31 & -9 & 31 & 58 & -11 \\
\hline Germany & $1984-2010$ & 1.64 & 0.55 & 1.09 & 0.21 & -0.02 & 0.55 & 0.25 & 0.09 & 20 & -2 & 51 & 23 & 8 \\
\hline Greece & $1995-2010$ & 2.06 & 2.00 & 0.06 & 0.19 & 0.30 & -0.51 & 0.19 & -0.12 & 334 & 534 & -896 & 332 & -204 \\
\hline Hungary & $1991-2012$ & 1.92 & -0.22 & 2.14 & 0.62 & 0.17 & 0.95 & 0.45 & -0.05 & 29 & 8 & 44 & 21 & -2 \\
\hline Iceland & 2004-2010 & 0.61 & -0.18 & 0.80 & 0.64 & 2.18 & -1.77 & 0.15 & -0.40 & 81 & 273 & -223 & 18 & -50 \\
\hline Ireland & $1987-2010$ & 4.17 & 3.19 & 0.99 & 0.15 & 0.47 & -0.05 & 0.63 & -0.21 & 15 & 47 & -5 & 64 & -22 \\
\hline Israel & $1986-2010$ & 2.14 & 1.59 & 0.56 & 0.11 & -0.20 & 0.30 & 0.12 & 0.22 & 20 & -35 & 53 & 22 & 40 \\
\hline Italy & $1986-2010$ & 1.06 & 0.83 & 0.24 & -0.26 & -0.01 & 0.07 & 0.45 & -0.00 & -109 & -5 & 27 & 187 & -1 \\
\hline Luxembourg & $1985-2010$ & 3.23 & 2.81 & 0.42 & -0.36 & 0.76 & -0.25 & 0.18 & 0.10 & -86 & 179 & -59 & 42 & 23 \\
\hline Netherlands & $1993-2010$ & 1.89 & 1.34 & 0.56 & -0.06 & -0.04 & 0.38 & 0.06 & 0.22 & -11 & -8 & 68 & 11 & 40 \\
\hline Poland & $1992-2010$ & 4.46 & 1.56 & 2.90 & 0.51 & -0.13 & 2.01 & 0.29 & 0.22 & 18 & -4 & 69 & 10 & 8 \\
\hline Slovak Rep & $1992-2010$ & 4.36 & 2.23 & 2.13 & 1.74 & 0.16 & -0.15 & 0.15 & 0.23 & 82 & 8 & -7 & 7 & 11 \\
\hline Slovenia & $1997-2010$ & 2.77 & 1.96 & 0.82 & 0.41 & 0.11 & -0.28 & 0.56 & 0.01 & 50 & 14 & -34 & 69 & 2 \\
\hline Spain & $1980-2010$ & 1.90 & 1.71 & 0.20 & -0.17 & 0.02 & -0.16 & 0.55 & -0.05 & -86 & 8 & -80 & 281 & -24 \\
\hline Sweden & $1981-2005$ & 1.98 & 1.89 & 0.09 & -0.14 & -0.08 & 0.30 & -0.16 & 0.16 & -147 & -82 & 327 & -174 & 177 \\
\hline Switzerland & 2000-2004 & 0.40 & 0.59 & -0.19 & 0.26 & 0.07 & 0.21 & 0.24 & -0.97 & -137 & -38 & -110 & -126 & 511 \\
\hline UK & $1979-2010$ & 1.94 & 1.73 & 0.21 & -0.38 & -0.05 & 0.01 & 0.30 & 0.34 & -183 & -23 & 3 & 142 & 160 \\
\hline USA & $1979-2013$ & 1.60 & 0.32 & 1.27 & 0.60 & -0.09 & 0.32 & 0.14 & 0.31 & 47 & -7 & 25 & 11 & 24 \\
\hline Average & & 2.17 & 1.60 & 0.57 & 0.11 & 0.13 & 0.03 & 0.26 & 0.03 & 20 & 24 & 5 & 45 & 6 \\
\hline Standard devi & & 1.04 & 1.26 & 0.97 & 0.54 & 0.46 & 0.69 & 0.19 & 0.32 & 105 & 131 & 237 & 111 & 123 \\
\hline
\end{tabular}




\section{DIFFERENCES IN PRICE DEFLATORS AND BETWEEN GDP}

\section{AND GNI}

\subsection{The role of differences in price deflators}

The GDP deflator and the Consumer Price Index (CPI) serve different purposes. The CPI measures the changes in prices of the goods and services consumed by the typical household while the GDP deflator relates to production rather than consumption and measures the prices of all domestically produced final goods and services in the economy (Lequiller \& Blades, 2006; see also Feldstein, 2017; Groshen et al., 2017; Syverson, 2017). The GDP deflator thus does not adjust for changes in prices of goods imported from other countries, but does, unlike the CPI, cover those of capital goods. The difference between the two - the 'terms of trade wedge' (Bivens and Mishel, 2015) - thus reflects a divergence in prices between the goods and services that households purchase and those that they produce. There are additional differences between the two deflators, such as in the formulae accounting for substitution due to relative price changes, the weighting of housing, coverage of medical expenses paid by individuals versus by public and private insurers, and in methodologies for computing price changes (Pessoa and Van Reenen, 2013). The point that must be emphasised here is that the differential behaviour of these price indices reflects actual dynamics in the economy rather than purely statistical issues, and these need to be taken into account in assessing and understanding the evolution of growth and living standards.

Table 1 column (2) shows the annual average change in GDP per capita deflated by the CPI rather than the GDP deflator, and comparison with column (1) allows us to see the difference this makes to the rate of real growth. We see that while the two series are very similar for most countries, there are some notable exceptions. Figure 4 highlights the difference in that respect between the UK and the USA. In the UK the CPI lagged the GDP deflator, whereas in the USA the CPI rose more rapidly than the GDP deflator throughout. This meant that in the USA, GDP per capita deflated with the GDP deflator grew by $1.6 \%$ per year on average compared to only $1.0 \%$ when deflated with the CPI. Thus, for the USA, prices for national output grew more slowly than prices for consumer purchases - households faced worsening terms of trade, as discussed in for example Bivens and Mishel (2015) and Fixler and Jaditz (2002). As those studies bring out, this reflected for example the fact that the price of 
investment goods rose more slowly than consumption goods, and that housing costs which play a significant role in consumption rose relatively rapidly there.

\section{United States}

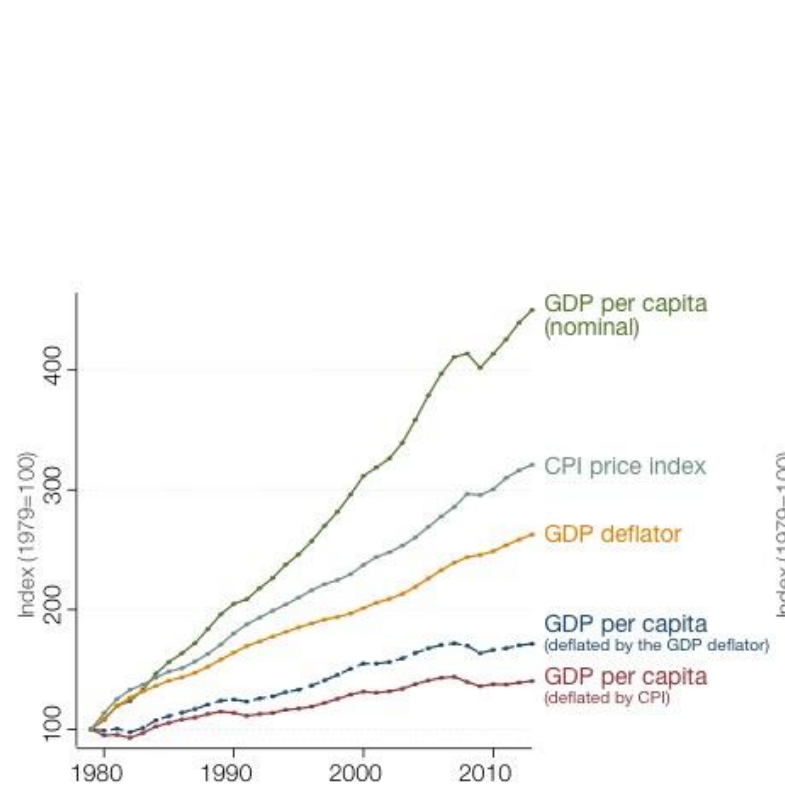

\section{United Kingdom}

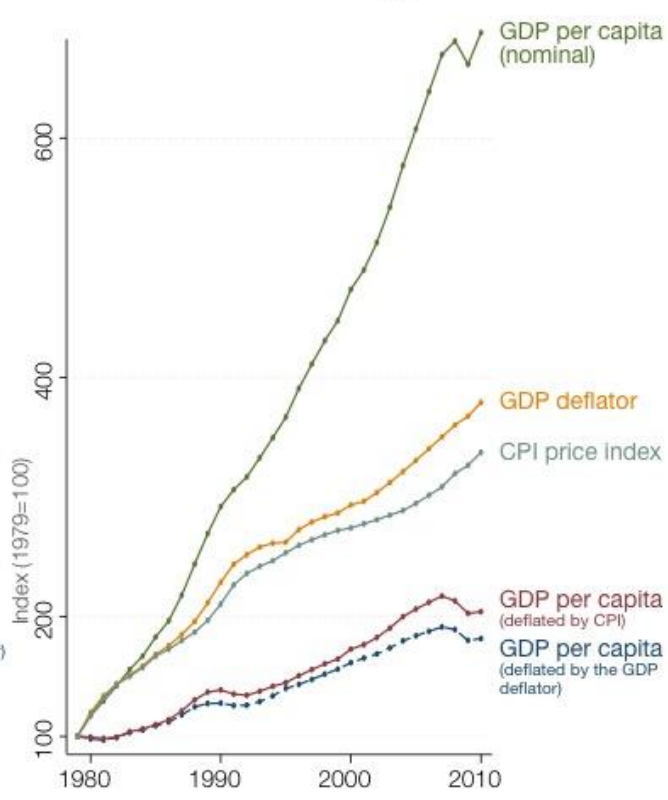

Figure 4: Evolution of GDP and GDP deflator and CPI in the USA and the United Kingdom

The contribution of differences in price deflators to the overall divergence is shown in Table 2 columns (4) and (9). We see that this contribution varies very considerably across countries. In the two countries at either extreme, Estonia and the Slovak Republic, the difference in deflators would serve to reduce or increase annual average growth in real income by as much as 1.5 percentage points. For a number of other countries (Austria, Hungary, Iceland, Norway, Poland, and the USA), that contribution is 0.5 percentage points or larger, more often reducing than increasing the growth rate as one moves from deflating with the GDP deflator to doing so with the CPI. The finding that price deflators matter substantially for the measurement of real income growth confirms Atkinson et al. (2015), who show that choices in correcting for price changes can be important in assessing real income developments across the EU-27 between 2005-2011. What our comparative study brings to light is how much the direction and scale of this effect can vary across countries. 


\subsection{The role of differences between GDP and GNI}

We adjust for price changes using the CPI from this point onwards and in the next step we focus on the difference in growth rates between GDP and GNI per head, shown in columns (2) and (3) of Table 1 respectively. There is little difference in the annual average growth rates for most countries. Table 2 confirms that apart from three notable exceptions that we will turn to, moving from GDP to GNI per capita does not contribute much to accounting for the divergence between GDP and median household income. When one excludes the three countries there is little remaining difference on average, and no other countries for which the difference between GDP and GNI average growth is larger than 0.5 ppt. Thus, generally, correcting for net factor income flows from abroad does not substantially affect income growth rates across countries.

For three countries the difference is very substantial: In Iceland, Ireland and Luxembourg GNI lagged substantially behind GDP. In Luxembourg and Iceland the difference between GNI and GDP was in fact the most important contributor to the total divergence. In Iceland GNI per capita was falling much more substantially and in the other two it was rising less rapidly. This reflects the scale of net factor outflows in these three cases, with a significant part of output flowing to no-resident entities. Figure 5 illustrates the trends for Luxembourg and Ireland. This shows that Luxembourg has a large discrepancy between GNI and GDP, as is well known (see also Zucman, 2015), but also a relatively low correlation between GNI and GDP over time, with GNI being particularly volatile (OECD, 2015). Ireland also has a pronounced gap between GNI and GDP, but in this case the correlation in growth rates is higher and the difference between GNI and GDP is less volatile. 
Luxembourg

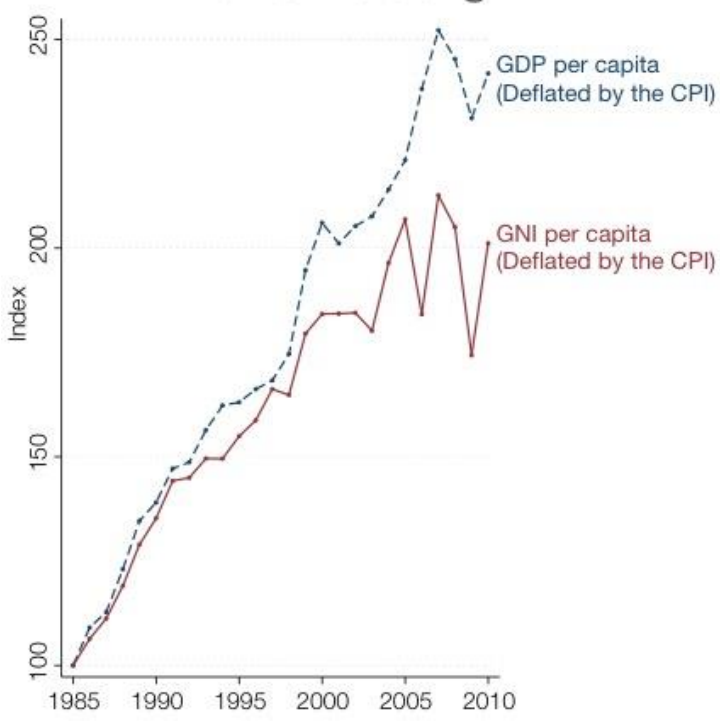

Ireland

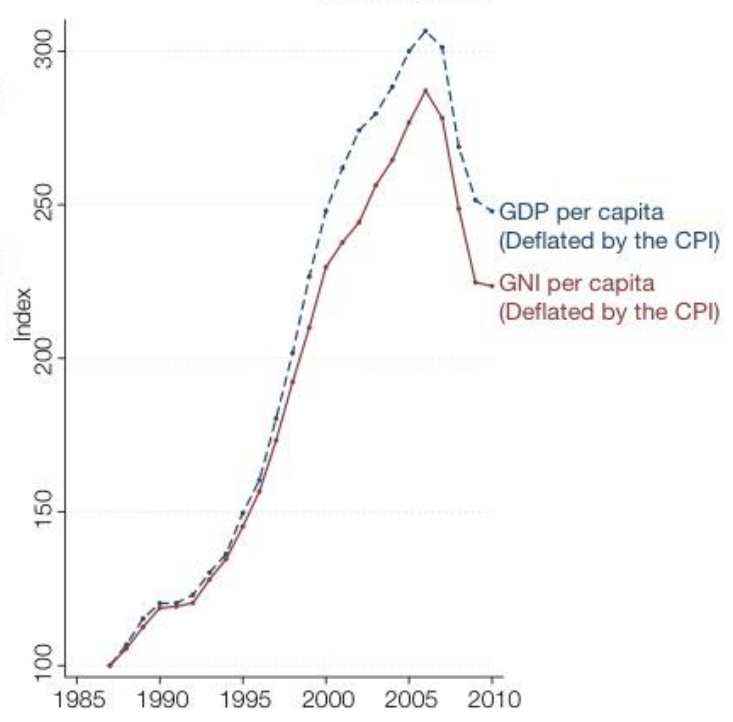

Figure 5: Evolution of GDP and GNI for Luxembourg and Ireland

\section{MEAN INCOME IN THE NATIONAL ACCOUNTS VERSUS HOUSEHOLD SURVEYS}

\subsection{The gap between GNI and household income per head}

We now turn to the difference between GNI per capita as measured in the national accounts and household income per capita as measured in household surveys, each deflated by the CPI. This is a central comparison in terms of whether these core indicators from different sources generally point in a similar direction. There are three main reasons why these two income measures might diverge. The first is that GNI refers to the entire economy rather than to the household sector in national accounts terms. The second is that there are differences between the income concepts employed for household sector income in the national accounts versus income in household surveys. Certain income sources such as imputed rent, retained profits, or in-kind benefits are taken into account in the national accounts but are (often) not reported in household surveys. The final reason relates to differences between the national accounts and household surveys in the actual measurement of incomes, with surveys not always reliably capturing the income from different sources that they aim to cover and national accounts aggregates also measured imperfectly.

Teasing out the impact of these different aspects is a very complex matter, to which the OECD-Eurostat Joint Expert Group mentioned earlier has devoted considerable effort (see especially Fesseau et al., 2013, and Fesseau and Mattonetti, 
2013). It is clear from these and other studies such as Endeweld and Alkemade (2014) and Atkinson et al. (2015) that both conceptual differences and survey underrepresentation of particular income sources are important and need further investigation. Deaton (2005) also provides a helpful discussion of the major elements involved, focused primarily on developing countries but including the USA and UK.

Ideally, one would like to distinguish the influence of these various reasons, but the data required to investigate them in depth are not available across all countries and periods we are covering. We first simply capture the extent of the difference between the two measures for the purpose of our overall accounting. We then employ regression analysis to examine the role of the various contributing factors, and conclude this section by delving deeper into the national accounts data for a sub-set of countries over a shorter time-span.

\subsection{What lies behind the gap between GNI versus household income growth?}

The average annual growth rates of GNI and the survey mean per capita are shown in Table 1 columns (3-4). What is initially striking, given the recent attention paid to the differences between the two sources and how best to reconcile them, is that there is little or no gap between the two in the annual average growth rates averaged across all the countries - that difference is only 0.03 percentage points. There are however substantial differences between the two CAGRs for some countries, in particular a number of Eastern European countries where average income in the surveys has grown less rapidly than GNI. There is also some gap in the same direction for the USA. But for other countries the difference is small.

Table 2 reports the contribution of this difference in Columns (6) and (11). While receiving considerable attention, the contribution is not always of great importance. It is worth noting that the contribution can go in either direction and that the variation across countries is extremely wide, varying from -1.77 in Iceland to 2.02 in Poland. In total there are nine countries for which this absolute difference is larger than 0.5 percentage points, and these are fairly evenly divided between cases where the household mean grew more slowly than GNI and others where it grew more rapidly. For the other two-third of the countries, the divergence in annual average growth rates is more modest, but for some this would still cumulate over several decades into a gap of $15 \%$ or $20 \%$ in total growth. Furthermore, as we shall see below, there may be substantial differences over shorter periods, making it even more 
hazardous to take the change in GNI per head as a proxy for that in mean household income in surveys.

We now employ regression analysis to gain further insight into factors driving the wedge between the national accounts and household surveys divergence. To maximise data coverage, we take the percentage point difference between the growth rates of GNI per capita and of mean household income per capita as the dependent variable. ${ }^{7}$ Following our discussions of potential factors contributing to the wedge, we examine the associations with four independent variables: (1) the top 1\% pre-tax and transfer income share from the World Top Incomes Database; (2) real in-kind social spending per head from OECD SOCX; (3) number of households interviewed in the LIS data; and (4) the response rate to the survey as collected from the LIS dataset descriptions. All variables are expressed in average annual growth rates. Because of gaps in data coverage of the top $1 \%$ shares and response rates, we end up with a significantly reduced sample of 59 observations, limiting even further how much we can say in greater detail.

The regression results in Table 3 show a significant positive association with the top $1 \%$ share, which corresponds to the hypothesis that rising top incomes contribute to driving a wedge between national accounts and survey income information. The OLS results also suggest a negative association between the number of households interviewed, as a rough quality indicator, and the wedge between GNI and household income per capita. No significant associations with in-kind social spending or response rates are found. However, these results can only be interpreted at best as indicative, given the low number of observations and the limited amount of explained variance, which may reflect the degree of heterogeneity across countries we highlight throughout.

\footnotetext{
${ }^{7}$ In Section 5.3 we derive an indicator of spendable income. Unfortunately, the possibilities of conducting regression analysis with the divergence between household income per capita are severely hampered by data availability. We end up having a sample of only 21 observations expressed in growth rates, showing no significant associations.
} 
Table 3: Explaining the divergence between growth in GNI and mean household income per capita

\begin{tabular}{lc}
\hline & $\begin{array}{c}\text { Dependent variable: divergence between GNI and mean growth } \\
\text { rate in ppt }\end{array}$ \\
\hline & $(1)$ \\
$\Delta$ Top 1\% share & $2.45^{* * *}$ \\
$\Delta$ Real in-kind social spending per capita & $0.01)$ \\
& 0.02 \\
Number of households in sample & $(0.38)$ \\
& $-0.04 * * *$ \\
$\Delta$ Response rate in survey & $0.08)$ \\
& 0.09 \\
Constant & $(0.12)$ \\
$\mathrm{N}$ & 0.01 \\
$\mathrm{R}^{2}$ & $(0.96)$ \\
\hline Note: $\mathrm{p}$-values in parentheses. $* \mathrm{p}<0.1 * * \mathrm{p}<0.05 * * * \mathrm{p}<0.01$ & 59 \\
\end{tabular}

\subsection{Household sector income in the national accounts versus surveys}

To conclude our discussion of the divergence between mean national income and mean household income, we delve deeper into the national accounts to derive a national accounts definition of income more aligned with household income as measured in surveys. This requires national accounts data for the household sector, which are mostly only available on a consistent basis in the OECD National Accounts from the early/mid-1990s, and even then only for some countries. Our aim is much more modest than those of recent efforts by the OECD and EU and by academic researchers to reconcile distributional measures from surveys with national accounts concepts and totals and develop Distributional National Accounts; here we seek to bring out the key sources of divergence and whether there is consistency across countries and over time in that regard.

For the subset of countries for which this is available, we derive two 'intermediate' income measures that help to link GNI per capita on the one hand and mean household income in surveys on the other. The first intermediate variable we look at is gross household disposable income (GHDI). Unlike GNI, this only includes income for households together with 'non-profit institutions serving households' (NPISH). Moreover, it excludes income arising from in-kind state provision of services. Thus, both in terms of income concept, this variable is better aligned with household income from a survey perspective. 
The second intermediate income measure we derive from the national accounts is 'spendable income', to use Atkinson's (2013) term. This adjusts GHDI for a number of items that are generally not included in household income as measured in surveys. These are most importantly the value of imputed rent ${ }^{8}$ and the national accounts adjustment for 'Financial Intermediation Services Indirectly Measured' (FISIM). ${ }^{9}$

Comparing the growth rates in GNI per capita, these two intermediate variables, and mean household income then helps in assessing the relative importance of different elements where divergence is to be seen. In measuring mean per capita household income from surveys we continue to rely on LIS, though now for the shorter period being covered and a restricted set of countries (with 220 observations in all).

These growth rates for each of these income variables are shown by country in Table 4. We see that, when both are averaged across countries, the difference in growth rates between the GNI and GDHI national accounts aggregates is modest. However, when we look at individual countries there are some marked differences: these go in both directions, with GHDI growth lagging GNI in some countries and exceeding it in others, thus offsetting each other when the overall average is derived. A gap of 0.5 or 1 percentage points is not uncommon, with GNI growing considerably faster than household sector income in Austria, Belgium, Italy, the Netherlands, and Sweden while household sector income grew more rapidly than GNI in France and Ireland. So the transmission of overall economic growth to the household sector cannot be taken for granted, and plays a part in explaining how a gap can emerge between GDP/GNI and household income.

\footnotetext{
${ }^{8}$ While imputed rent is sometimes estimated and included in household survey data, and that is the approach recommended by the Canberra Report, this is not the common practice to date in LIS.

${ }^{9}$ FISIM is measured as the interest paid to banks and other intermediaries less interest paid by them. This is taken to be a measure of the value of financial intermediation and, since the 1993 revision of the SNA, has been added to national accounts estimates of household income. A similar item is included for risk-bearing services, measured from the profits of insurance companies.
} 
Table 4: Average annual growth in different national accounts income concepts and mean per capita household income from surveys

\begin{tabular}{|c|c|c|c|c|c|}
\hline & Years & $\begin{array}{l}\text { GNI per capita } \\
\text { CPI }(\%)\end{array}$ & $\begin{array}{l}\text { GDHI per capita } \\
\text { CPI } \\
(\%)\end{array}$ & $\begin{array}{c}\text { Spendable } \\
\text { income per } \\
\text { capita CPI } \\
(\%)\end{array}$ & $\begin{array}{c}\text { Mean income per } \\
\text { capita CPI } \\
(\%)\end{array}$ \\
\hline & & (1) & (2) & (3) & (4) \\
\hline Austria & 1997-2004 & 1.58 & 1.07 & 1.04 & 2.18 \\
\hline Belgium & $1995-2000$ & 2.21 & 0.90 & 0.59 & 3.36 \\
\hline Czech Republic & $1996-2010$ & 1.46 & 1.85 & 1.48 & 2.73 \\
\hline Denmark & $2000-2007$ & 2.03 & 1.81 & 1.42 & 1.50 \\
\hline Estonia & $2000-2010$ & 4.88 & 4.74 & 5.08 & 5.69 \\
\hline Finland & 1995-2010 & 2.78 & 2.70 & 2.45 & 2.70 \\
\hline France & $2000-2010$ & 0.66 & 1.07 & 0.99 & 1.95 \\
\hline Germany & $2000-2010$ & 0.75 & 0.44 & 0.49 & 0.24 \\
\hline Greece & $2007-2010$ & -3.93 & -3.57 & -3.85 & -2.87 \\
\hline Hungary & 1999-2012 & 1.64 & 1.22 & 1.12 & 1.37 \\
\hline Ireland & $2000-2010$ & -0.28 & 1.23 & 1.19 & 1.31 \\
\hline Italy & 1995-2010 & 0.68 & 0.07 & -0.32 & 1.06 \\
\hline Netherlands & 1999-2010 & 1.29 & 0.35 & 0.15 & 0.98 \\
\hline Slovak Republic & 1996-2010 & 2.34 & 2.87 & 2.76 & 3.20 \\
\hline Slovenia & $1997-2010$ & 2.25 & 2.05 & 2.02 & 2.53 \\
\hline Spain & $2000-2010$ & 0.91 & 0.59 & 0.14 & -0.09 \\
\hline Sweden & 1995-2005 & 3.52 & 2.40 & 2.51 & 2.72 \\
\hline United Kingdom & 1999-2010 & 2.10 & 2.22 & 2.02 & 2.07 \\
\hline United States & $2000-2013$ & 0.65 & 0.92 & 0.81 & 0.07 \\
\hline Average & & 1.45 & 1.31 & 1.16 & 1.72 \\
\hline
\end{tabular}

The comparison between GDHI and spendable income reveals more modest differences between these growth rates, but still considerable - of the order of 0.3-0.5 percentage points - for certain countries (such as Czech Republic, Italy, Spain) over the period available. Comparing spendable income with mean income in the household surveys, though, reveals some much larger differences, and in a direction that may be unexpected given the initial source of concern being household incomes lagging behind national accounts aggregates. Mean disposable household income as measured in the surveys is seen to have grown considerably faster than spendable income in Austria, Belgium, Czech Republic, France, Greece, Italy, and the Netherlands, whereas it lagged behind spendable income in the national accounts to a 
substantial degree only in the USA. This may well be specific to the period covered, but is nonetheless striking.

Recent studies such as Endeweld and Alkemade (2014) comparing national accounts and LIS survey data by income source, like other such studies on a national or comparative basis including those organized by the OECD and Eurostat referenced earlier, suggest that while differences in definition matter, surveys are particularly prone to missing specific income sources such as income from capital and selfemployment, as well as the tails of the income distribution. This is clearly of major concern where surveys are the basis for assessing income levels as the central indicator of living standards and their distribution, but might not necessarily have such serious implications in capturing changes in incomes and living standards over time for most of the distribution. However, our findings suggest that there can indeed be substantial differences in the income growth over time if one relies on household income in the national accounts versus household surveys, reinforcing the conclusion that efforts to bring together and integrate these sources more effectively need to be supported and intensified.

\section{THE ROLES OF CHANGING HOUSEHOLD SIZE AND INEQUALITY}

In this section we look closer at the divergence between mean per capita and median equivalised income, both taken from household surveys. Two factors can contribute to a divergence; namely, household size and inequality.

\subsection{Household size}

The next factor to be analysed is the difference between the growth rate of income per capita as captured in household surveys and of equivalised income in the same surveys, shown in columns (4-5) of Table 1 respectively. Individuals living with others in households benefit from economies of scale in consumption. This is what equivalence scales aim to capture. Declining average household size means reduced scope for economies of scale and will ceteris paribus therefore lower growth in equivalised median income compared to a per capita income concept.

We see from Table 1 that the growth in equivalised income was lower than that in income per head in 25 out of the 27 countries, the exceptions being Denmark 
and Sweden. Column (10) of Table 1 shows what underlies this: average household size declined in all but those two countries. In the two countries in which it increased it only did so slightly. The extent of the decline in household size varied across the other countries: across the entire set of observations the average number of household members went down by $0.5 \%$ per year on average, but the decline was up to twice as large in some countries.

To illustrate, Figure 6 plots average household size over time for the eight countries for which we have data from around 1980 onwards. We see a particularly rapid decrease in Spain (from 3.7 to 2.7 between 1980-2010) and a slight increase in Sweden (from 1.9 to 2.0 between 1981-2005).

As can be seen from columns (7) and (12) in Table 2, the difference between household income per capita versus equivalised income is an important contributor to the overall divergence we are accounting for. Income per capita grew faster (or decreased less) than mean equivalised income in all the countries covered except for Denmark and Sweden; the percentage point reduction in measured growth produced by this factor was substantial, in the 0.2-0.6 range for most countries. Since this aspect changed in the same direction in the great majority of countries it has by far the greatest average contribution of all factors -0.26 percentage points or $0.45 \%$ of the total divergence we aim to explain if we were to pool the data across countries.

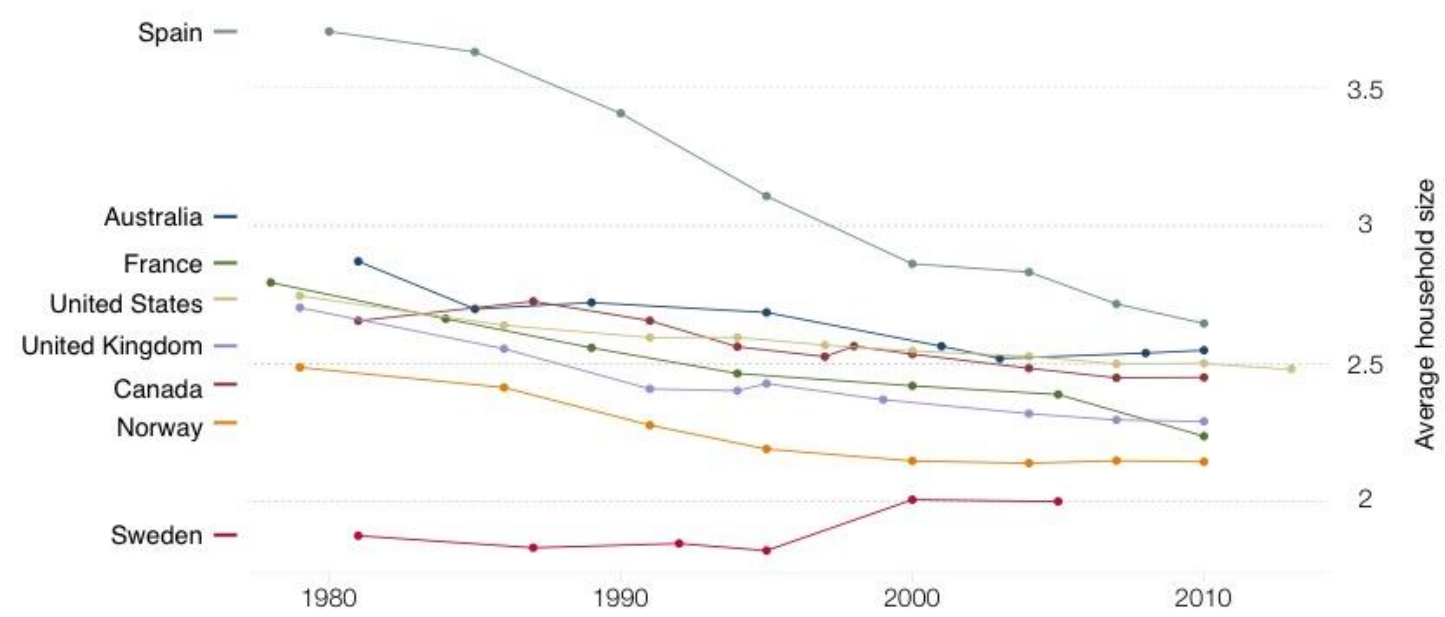

Figure 6: Evolution of average household size in 8 countries

6.2 Mean versus median income: The role of changing income inequality 
The final factor to be incorporated into our analysis is the fact that mean and median income may not evolve over time in the same way, if the way income is distributed is changing.

From comparing columns (5-6) of Table 1 it can be seen that growth in the median lagged behind that in the mean in about half of the studied countries. For a number of others there was little difference between the two, while for four countries the median grew more rapidly.

Over time, the median growing less rapidly than the mean generally reflects an increase in inequality. ${ }^{10}$ Mean household income will outpace income growth at the median if incomes grow faster in the top half of the distribution as a country experiences rising income inequality. It is therefore relevant to study how inequality has changed. The change in the Gini coefficient for equivalised income is shown in Table 1 column (11), and we see that in most countries in which the median has lagged behind the mean inequality has increased and vice versa. ${ }^{11}$ The average annual change in the Gini coefficient is indeed strongly correlated $(0.78)$ with the difference in growth between the mean and the median.

The contribution of the difference in growth rates between mean versus median equivalised income can be seen from columns (8) and (13) of Table 2. In Belgium, the UK and the USA this difference contributes more than 0.3 percentage points to the overall divergence, and a substantial contribution in the other direction is seen for Estonia, Iceland and Switzerland.

\subsection{Explaining the divergence between mean per capita and median equivalised} household income

To study the evolution of median equivalised income, it is instructive to examine the contribution of the relevant factors - the change in mean per capita income, in average household size, and in income inequality - simultaneously. Table 5 shows the estimation results for a simple OLS regression model using our pooled dataset, with

\footnotetext{
${ }^{10}$ Here we refer to 'generic' inequality across the bottom $99 \%$ of the distribution. As discussed above, an increase in the top $1 \%$ income share is generally not well captured in household surveys and will therefore most likely be reflected in the difference between mean per capita household income and GNI or spendable income per capita from the national accounts.

${ }^{11}$ In principle the mean could grow also grow more rapidly than the median because incomes below the median increased more rapidly in proportionate terms than those above it (though not enough for re-ranking to drive up the median), in which case inequality would decline. We test for this possibility in sub section 6.3 .
} 
all variables expressed in average annual growth rates. In this regression, the change in median equivalised income is first related to that in mean per capita income only (column 1); the change in average household size or the Gini coefficient are added in columns (2) and (3) respectively, while in column (4) all three explanatory variables are included. ${ }^{12}$ We see that while the mean alone is very strongly correlated with the median, both household size and inequality are also significant in predicting the latter and increase the $\mathrm{R}^{2}$ from 0.92 to 0.97 . When these variables are also included, the coefficient of mean per capita income is no longer statistically significantly different from 1 ( $p$ value of 0.60$)$.

From our regression results we can conclude that trends in average household size and inequality account for almost the entire difference over time in the path of mean per capita and median equivalised income. ${ }^{13}$ This suggests that the income distributions are of a standard log-normal type in which inequality increases as the ratio of the mean to median increases, the Gini index is sufficient to capture the difference between median and mean. Also, the general decrease in household size, rather than what is happening to household size and composition in particular parts of the income distribution, suffices to bridge the gap between per capita and equivalised income. Thus, for this part of the divergence, the contributing factors are quite clear.

Table 5: Explaining median equivalised income by mean per capita income, household size, and income inequality

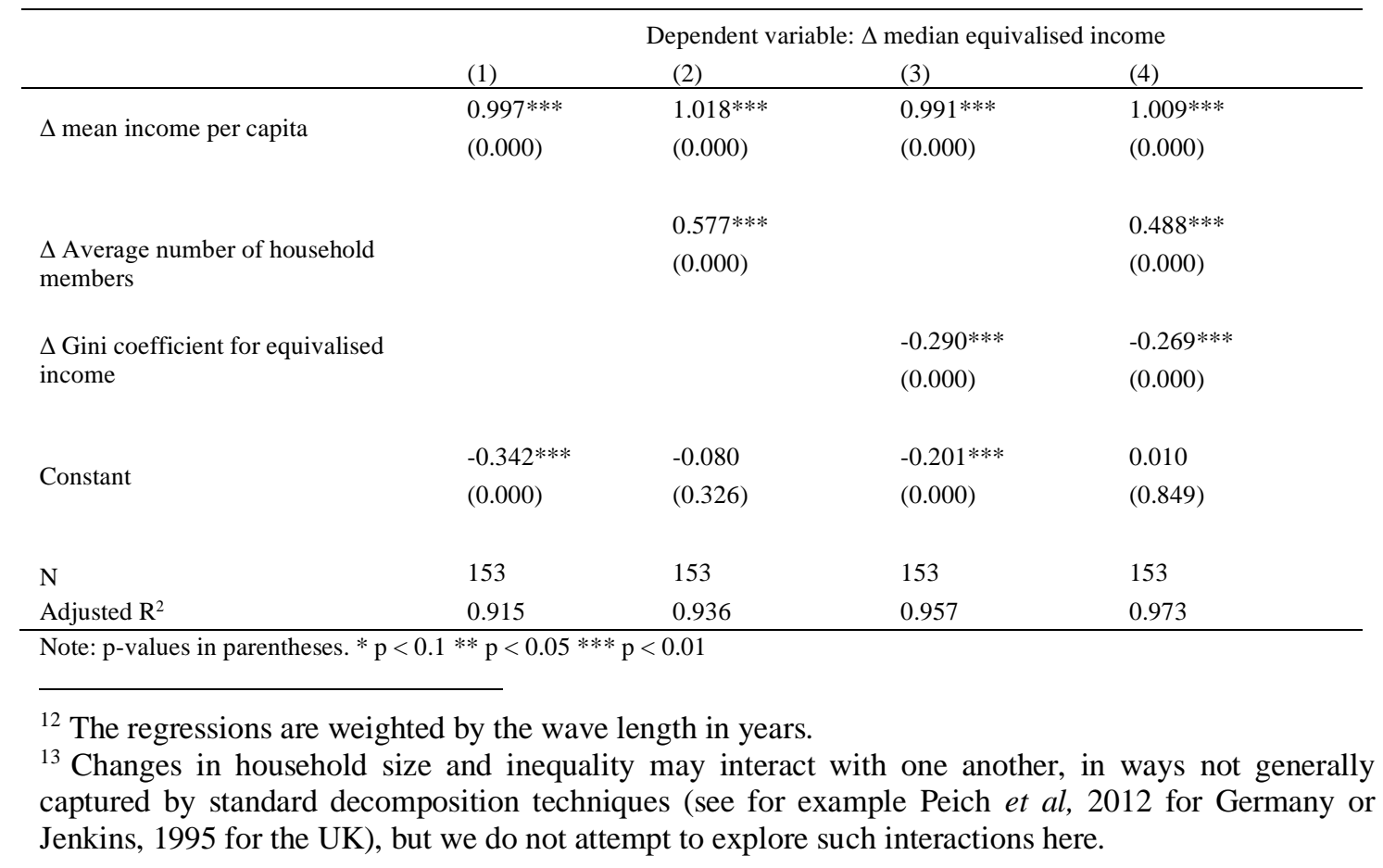




\section{WHAT DRIVES THE DIVERGENCE BETWEEN GDP AND MEDIAN HOUSEHOLD INCOME?}

'Headline' findings from the results we have presented from our comparative study of 27 countries are:

1) The scale of the divergence between growth in GDP per capita and in median household income over time varies greatly across countries; and

2) The factors contributing to this divergence also vary a great deal across the countries studied.

The implications of these findings are first that one should be extremely cautious about extrapolating from the experience of a single country - no matter how important - to what has been happening elsewhere and drawing general lessons on that basis. Secondly, while increasing income inequality has featured extensively in discussions of the GDP-median divergence, as it has in other contexts of late, it does not in fact emerge as a dominant contributor in most countries - in 17 of the countries we studied, declining household size contributed more to the divergence. Finally, teasing out the relationship between income change in the national accounts versus household surveys is an important task, but much of the explanation for the GDPmedian income divergence lies elsewhere and can be seen from analysis of data already to hand. Finally, the divergence within household surveys between median equivalised and mean per capita income can be understood very well by looking at generic inequality and household size trends.

It is worth bringing out these messages by looking in Figure 7 at five large OECD economies for which long runs of data are available. 'Waterfall charts' illustrate the size of the GDP-median divergence and the contribution of the various factors. The country that dominates much of the debate on these topics, the USA, is a clear outlier in the overall extent of the gap, with only Germany coming close. This is reflected in the fact that the scale we have to employ for these two countries in the charts is much wider than for the other three countries. ${ }^{14}$ The USA is also distinctive in the size of the contribution to this divergence of growing income inequality, as reflected in the gap between mean and median income, and of the difference between the producer versus consumer prices. So even when one looks at two countries where

\footnotetext{
${ }^{14}$ We do not include the UK, another large OECD country, in this comparison because the extent of the divergence there is relatively limited.
} 
the extent of the overall GDP-median divergence is similarly large, the factors underpinning that divergence are quite different.
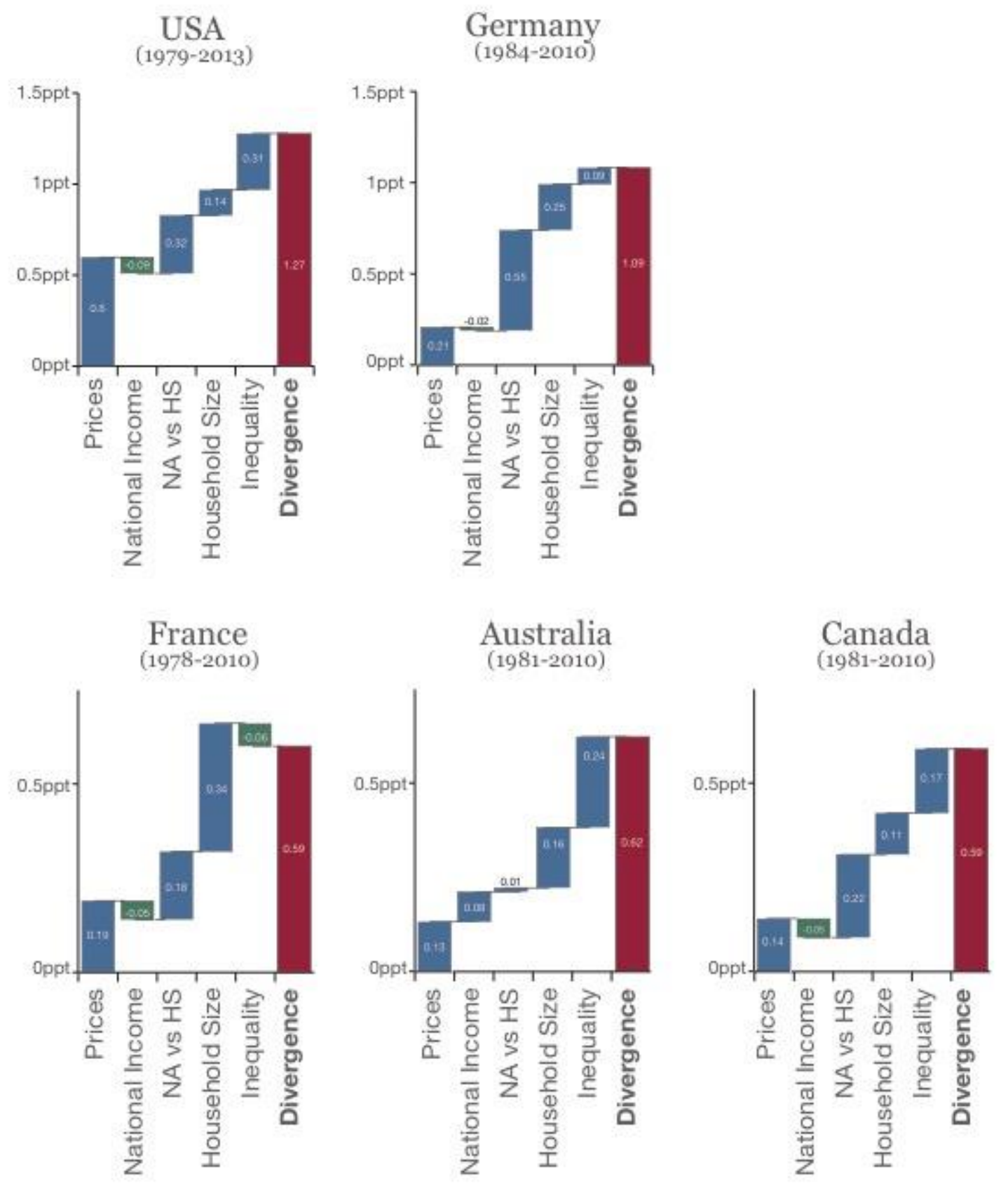

Figure 7: The breakdown of the contributors to the total divergence over the longest available period for five countries

As mentioned earlier, the ordering in which the various factors are taken in the decomposition is to some extent arbitrary - in terms for example of whether price deflators are examined first or last, or whether one looks at equivalisation and then inequality or vice versa. The detailed results found when we employ the full range of 
different possible orderings are given in Appendix 1, demonstrating that the results of the decomposition are robust to alternative orderings. The effect of price deflators, GNI versus GDP, and GNI versus mean household income remain very similar; the only difference is that looking at inequality first and then per capita versus equivalised income (rather than vice versa) increases the contribution of falling household size somewhat.

\section{INVESTIGATING AND DECOMPOSING THE GDP-MEDIAN DIVERGENCE OVER TIME}

The extent of the divergence between GDP per capita and median equivalised household income and the factors producing that divergence might well vary not just across countries, but for a particular country over different time-periods. We now examine the extent to which this is the case for the large countries discussed in the previous section, for which LIS has data going back to the early/mid-1980s. We focus our discussion here on the decomposition results in terms of percentage point contributions, while the full decomposition results along the same lines as Table 2 (including percentage contributions and underlying annual growth rates) are given in Appendix 2.

We start with the USA, which as highlighted earlier is often taken as the exemplar or basis for discussion in this domain. Table 6 shows the GDP-median divergence and decomposition results by sub-period for the USA. We see that the divergence between growth in GDP per capita and the household median, which we saw earlier was very pronounced over the whole period, was also substantial in most of the sub-periods distinguished - the exception being the 2007-10 period when the Great Recession struck. There is much less consistency across periods in the contribution of the various factors, though - with household size and inequality contributing most in the 1980s, the gap between GNI in the national accounts and mean income in surveys being a substantial contributor from 1997-2004, and with the difference between the GDP deflator and CPI being very important up to 2000 but less so subsequently. 
Table 6: Decomposing the GDP-median household income divergence for different time-periods: USA

\begin{tabular}{lcccccccccc}
\hline Years & $1979-$ & $1979-$ & $1986-$ & $1991-$ & $1994-$ & $1997-$ & $2000-$ & $2004-$ & $2007-$ & $\begin{array}{c}2010- \\
2013\end{array}$ \\
\hline (A) Divergence & 2013 & 1986 & 1991 & 1994 & 1997 & 2000 & 2004 & 2007 & 2010 & 1.31 \\
\hline (B) ppt & 1.27 & 1.72 & 1.52 & 2.28 & 0.73 & 0.87 & 1.17 & 1.17 & -0.03 & 1.37 \\
contribution & & & & & & & & & & \\
Prices & 0.60 & 0.75 & 1.02 & 0.60 & 0.82 & 0.75 & 0.20 & 0.17 & 0.37 & 0.38 \\
National income & -0.09 & 0.12 & -0.08 & 0.21 & -0.58 & -0.40 & 0.13 & 0.02 & -0.10 & -0.50 \\
NA vs HS & 0.32 & 0.06 & 0.13 & 0.01 & 0.18 & 0.77 & 0.79 & 0.51 & -0.06 & 0.80 \\
Household size & 0.14 & 0.39 & 0.21 & -0.15 & 0.24 & -0.03 & -0.01 & 0.23 & -0.01 & 0.04 \\
Inequality & 0.31 & 0.40 & 0.23 & 1.60 & 0.07 & -0.21 & 0.06 & 0.25 & -0.23 & 0.60 \\
\hline
\end{tabular}

Figure 8 brings together this time dimension and the waterfall chart showing the contribution of each factor over the entire period. It reveals that the divergence was substantial in most of the sub-periods, as median incomes were essentially stagnant except between 1995 and 2001.
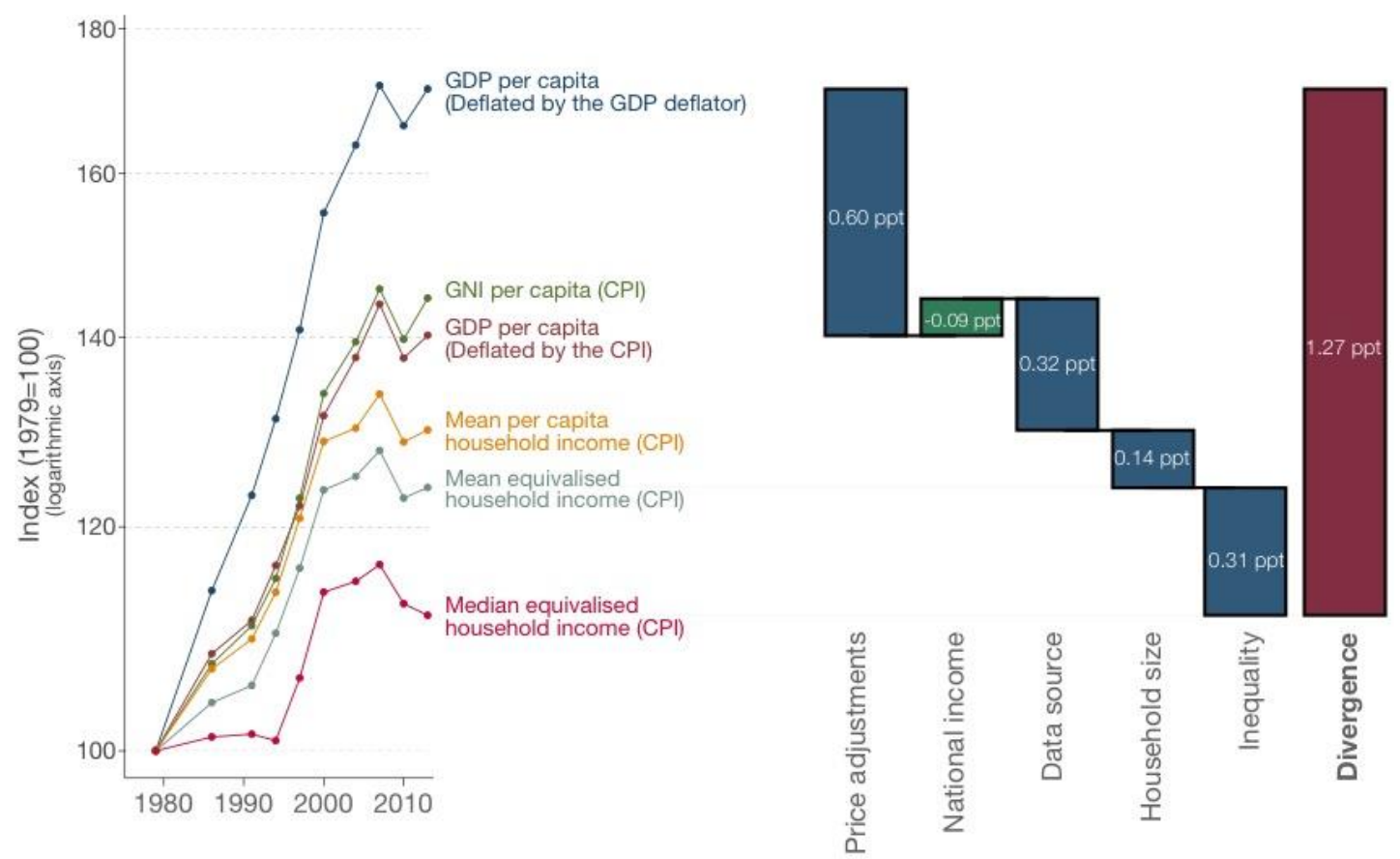

Figure 8: Decomposing the divergence between median household income and GDP per capita for the US over time

We compare these patterns for the USA first with two other large "AngloSaxon/liberal' countries, Australia and Canada. In Table 7 we see that in the case of Australia, there was also a substantial divergence between GDP per capita and median household income in most of the sub-periods up to 2003, though median income grew 
much faster than GDP from 2003-2008. ${ }^{15}$ Differences between the price deflators make an important contribution up to the mid-1990s, with the GDP deflator rising more rapidly than the CPI, but work strongly in the opposite direction from 2003 onwards. Household size and inequality do so only in certain sub-periods, and the GNI-mean household income gap is important from 1985-95.

Table 7: Decomposing the GDP-median household income divergence for different time-periods: Australia

\begin{tabular}{lcccccccc}
\hline Years & $1981-$ & $1981-$ & $1985-$ & $1989-$ & $1995-$ & $2001-$ & $\begin{array}{c}2003- \\
2008\end{array}$ & $\begin{array}{c}2008- \\
2010\end{array}$ \\
\hline (A) Divergence & 2010 & 1985 & 1989 & 1995 & 2001 & 2003 & -4.81 & 0.63 \\
\hline (B) ppt contribution & 0.62 & 1.53 & 2.09 & 2.88 & 0.70 & 1.90 & & \\
Prices & & & & & & & & \\
National income & 0.13 & 0.69 & 0.65 & 1.35 & 0.18 & -0.34 & -1.57 & -1.20 \\
NA vs HS & 0.08 & -0.03 & 0.46 & 0.03 & -0.14 & 0.07 & 0.14 & 0.28 \\
Household size & 0.01 & -0.04 & 0.52 & 1.55 & 0.22 & 1.12 & -3.66 & 1.48 \\
Inequality & 0.16 & 0.80 & -0.09 & -0.12 & 0.39 & 0.66 & -0.13 & -0.30 \\
\hline
\end{tabular}

From Table 8 we see that Canada also saw a substantial divergence between GDP per capita and median household income in most of the sub-periods distinguished up to 2000 , being particularly marked in the late 1990s, but the median grew more rapidly from then onwards especially from 2004-2007. The factors responsible again varied considerably over time, with differences between the price deflators important in the 1980s and late 1990s, household size and inequality intermittently contributing, and the GNI-mean household income gap the main contributor to the pronounced overall divergence in the late $1990 \mathrm{~s}$.

Table 8: Decomposing the GDP-median household income divergence for different time-periods: Canada

\begin{tabular}{lcccccccccc}
\hline Years & $1981-$ & $1981-$ & $1987-$ & $1991-$ & $1994-$ & $1997-$ & $1998-$ & $\begin{array}{c}2000- \\
2004\end{array}$ & $\begin{array}{c}2004- \\
2007\end{array}$ & $\begin{array}{c}2007- \\
2010\end{array}$ \\
\hline (A) Divergence & 0.59 & 1.11 & -0.04 & 1.49 & 1.89 & 1.30 & 4.61 & -0.28 & -1.24 & -1.70 \\
\hline $\begin{array}{l}\text { (B) ppt } \\
\text { contribution }\end{array}$ & & & & & & & & & & \\
Prices & 0.14 & 0.68 & 0.90 & -0.25 & 0.07 & 1.23 & -0.85 & -0.01 & -0.93 & 0.05 \\
National income & -0.05 & -0.04 & 0.06 & 0.09 & -0.17 & 0.27 & -0.40 & -0.12 & -0.24 & 0.16 \\
NA vs HS & 0.22 & 0.43 & -1.33 & 1.04 & 1.84 & -1.15 & 4.69 & -0.42 & -0.43 & -1.53 \\
Household size & 0.11 & -0.10 & 0.16 & 0.60 & 0.16 & -1.12 & 0.10 & 0.29 & 0.24 & -0.04 \\
Inequality & 0.17 & 0.14 & 0.18 & 0.00 & -0.01 & 2.07 & 1.07 & -0.01 & 0.12 & -0.33 \\
\hline
\end{tabular}

\footnotetext{
${ }^{15}$ Note that the specific sub-periods distinguished vary across the countries reflecting the availability of data in LIS.
} 
Finally, we look at two other major OECD economies, France and Germany. From Table 9 we see that France saw a substantial divergence between GDP per capita and median household income in specific sub-periods up to 2005 , notably through the 1980s and in the second half of the 1990s. The GNI-mean household income gap was an important contributor to that divergence, while household size and the difference between price deflators also contributed and with inequality being important only from 1989-1994.

Table 9: Decomposing the GDP-median household income divergence for different time-periods: France

\begin{tabular}{lccccccc}
\hline Years & $1978-$ & $1978-$ & $1984-$ & $1989-$ & $1994-$ & $2000-$ & $2005-$ \\
2005 & 2010 \\
\hline (A) Divergence & 2010 & 1984 & 1989 & 1994 & 2000 & -2.21 \\
\hline (B) ppt contribution & 0.59 & 2.12 & 1.64 & -0.96 & 2.23 & 0.09 & \\
Prices & & & & & & & \\
National income & 0.19 & 0.62 & -0.33 & 0.55 & 0.29 & 0.00 & -0.13 \\
NA vs HS & -0.05 & 0.13 & -0.19 & -0.01 & -0.23 & 0.02 & -0.06 \\
Household size & 0.18 & 0.74 & 2.84 & -2.70 & 2.26 & 0.15 & -2.76 \\
Inequality & 0.34 & 0.39 & 0.35 & 0.45 & 0.15 & 0.16 & 0.60 \\
& -0.06 & 0.23 & -1.03 & 0.76 & -0.24 & -0.25 & 0.14 \\
\hline
\end{tabular}

For Germany, Table 10 shows that there was a particularly pronounced divergence between GDP per capita and median household income in the late 1980s-early 1990s, when unification took place, but that there was a further gap up to 2007. The gap between GNI per capita and household income was particularly important in contributing to that overall divergence from 1989-1994 and 2004-2007 but worked in the opposite direction from 1994-2004, when household size and inequality were the most substantial contributors.

Table 10: Decomposing the GDP-median household income divergence for different time-periods: Germany

\begin{tabular}{lccccccc}
\hline Years & $1984-$ & $1984-$ & $1989-$ & $1994-$ & $2000-$ & $\begin{array}{c}2004- \\
2007\end{array}$ & $\begin{array}{c}2007- \\
2010\end{array}$ \\
\hline (A) Divergence & 2010 & 1989 & 1994 & 2000 & 2004 & -0.59 \\
\hline (B) ppt contribution & 1.09 & 0.10 & 2.99 & 0.49 & 0.46 & 3.28 & \\
Prices & & & & & & & \\
National income & 0.21 & -0.96 & 0.18 & 0.79 & 0.29 & 0.94 & -0.22 \\
NA vs HS & -0.02 & -0.05 & 0.31 & 0.13 & -0.34 & -0.26 & -0.16 \\
Household size & 0.55 & 0.54 & 2.10 & -0.66 & -0.24 & 1.92 & 0.11 \\
Inequality & 0.25 & 0.32 & 0.32 & 0.20 & 0.32 & 0.32 & -0.01 \\
\hline
\end{tabular}




\section{CONCLUSIONS}

The stark contrast between growth in real GDP per capita versus stagnation (for the most part) in median household income in the USA has fuelled unease about relying on GDP growth as the core indicator of economic performance and living standards there. While previous studies have sought to tease out what lies behind this divergence in the USA, and for several other countries, it has not been investigated comparatively. That has been the aim of this paper, bringing together data covering recent decades from the Luxembourg Income Study and the OECD National Accounts for 27 OECD countries. Applying a common analytical framework has allowed us not only to measure the extent of this divergence but also assess the factors that contribute to it, and thus highlight the underlying dynamics and how these differ across countries and over time.

Our results reveal first that while GDP per capita did rise faster than median household income in most of these countries over the period covered (which itself differs across countries), the size of that divergence varied very substantially. In most cases, it was not as large as in the USA, which was also distinctive in combining such a large divergence with very little growth in the median in real terms. Germany comes closest to that experience among the major economies.

The paper then distinguished five factors which could drive a divergence between growth in GDP per capita and median household income: differences between price deflators, between GDP and GNI, between mean income as measured in the national accounts versus household surveys, between per capita and equivalised mean income in surveys, and between the mean and the median of the household income distribution in surveys. Most of these factors made a substantial contribution in accounting for the overall divergence in the case of the USA, but once again this was found to be far from typical.

The impact of differing price deflators varied both in size and direction across countries, but played in absolute terms a relevant role in the extent to which economic growth transmits to income gains for ordinary households. On average, but with substantial variation across countries and over time as noted, the GDP deflator rose less fast than the consumer price index, meaning that prices went up faster for consumers than for producers. The GDP-GNI distinction was important for only a few countries known to have large net factor outflows. Differences between the national 
accounts and household surveys, on which we reflect more below, have received considerable recent attention in the research and statistical communities, but were important for some countries but often less so than other factors. The same is true of the other factor that has been the focus of such attention for the US case, namely increasing income inequality (as reflected in a growing gap between the mean and median as measured in surveys). A generally neglected factor in this context, declining household size, was found to be the most consistent in its impact, widening the gap between GDP per capita and median equivalised income over time in most countries. The decline in average household size leads to a reduction of economies of scale for households, lowering growth in equivalised income for ordinary households. The divergence between mean per capita and median equivalised income in surveys was seen to be fully explained by reference to the evolution of the Gini coefficient and average household size.

In addition to variation across countries, we also found there to be considerable variation across time-periods for individual countries in the extent and drivers of GDP-median divergence. Declining household size is again the most consistent in its effects, but for the other factors distinguished, however, not only the size but sometimes the direction of the effect varied from one sub-period to another. The extent of this variation across countries and over time underlines the importance of the comparative approach adopted here: extrapolating from previous studies focused on single countries would be quite unsafe.

The gap between income as measured in the national accounts versus household surveys was also explored here in more depth, over the shorter period for which the components of household sector income are distinguished in the national accounts. This showed that the differences between GNI and household sector income, between the latter and a 'spendable income' concept also derivable from the national accounts but excluding items that will not (generally) be measured in household surveys, and between that figure and income as actually measured in household surveys each contributes to the GNI-mean household income gap.

Our findings mean that efforts under way by researchers, statistical agencies and international organisations to improve the links between national accounts and survey-based data and income concepts clearly need to be supported and intensified. However, our findings highlight that other factors also drive a wedge between GDP per capita and median equivalised household income, and that these reflect important 
real-world phenomena rather than statistical artefacts. Reduction in household size, and rising prices of consumer goods, and to a lesser extent an increase in inequality and net factor outflows leads to a lower transmission of economic growth to median household equivalised income.

More generally, these findings have serious implications for the monitoring and assessment of living standards for 'ordinary' or 'typical' households over time. Atkinson et al. (2015) conclude on the basis of their comparison between median household equivalised income and GDP per capita for EU countries from 2005 to 2011 that the trends revealed by the two measures are largely comparable. Our findings over a longer period across a broader range of OECD countries are that this divergence may well be substantial, that it varies across countries and over different time-periods, and is the product of different underlying dynamics at different times. Given the difficulty of assessing the likely impact of these factors in 'real time', a central implication of our findings is that median income should to be accorded a central role alongside GDP per capita in both official monitoring of living standards and how they are changing over time and in research on inclusive growth.

In this paper we are able to provide a thorough understanding of the divergence between median equivalised and mean per capita income. However, why in certain countries and periods prices for consumers did not rise on par with producer prices is an important question for future research (e.g., Feldstein, 2017; Groshen et al., 2017; Syverson, 2017). Additionally, gaining better insight into the divergence between mean per capita from the national accounts and household surveys remains an important research topic. Our paper provides a first test of factors that play a role here.

\section{REFERENCES}

Aaberge, R. and A.B. Atkinson, "The median as watershed", Statistics Norway Discussion papers no. 749, Statistics Norway, 2013.

Atkinson, A.B., "Putting people first and macro-economic policy", European Commission Economic Papers 481 (part II), 39-64, 2013.

Atkinson, A.B., E. Marlier and A.-C. Guio, "Monitoring the evolution of income poverty and real incomes over time". CASE Paper 188, Centre for Analysis of Social Exclusion, London School of Economics, London, 2015.

Atkinson, A.B., L. Rainwater and T. Smeeding, Income distribution in OECD countries: The evidence from the Luxembourg Income Study, Organization for Economic Cooperation and Development, Paris, 1995. 
Boarini, R., F. Murtin and P. Schreyer, "Inclusive growth: The OECD measurement framework", OECD Statistics Working Papers, 2015/06, Organization for Economic Cooperation and Development, Paris, 2015.

Bhalla, S. S., Imagine There's No Country - Poverty, Inequality, and Growth in the Era of Globalization. Peterson Institute for International Economics, Washington DC, 2002.

Bivens, J. and L. Mishel, "Understanding the Historic Divergence between Productivity and a Typical Worker's Pay", EPI Briefing Paper 406, Economic Policy Institute, Washington DC, 2015.

Causa, O., A. de Serres, and N. Ruiz, "Can Pro-Growth Policies Lift all Boats?", OECD Economics Department Working Papers, Organisation for Economic Co-operation and Development, Paris, 2015.

Coyle, D., GDP: A Brief but Affectionate History, Princeton University Press, Princeton, 2015.

Deaton, A., "Measuring Poverty in a Growing World (or Measuring Growth in a Poor World)", Review of Economics and Statistics, 87(1), 1-19, 2005.

Endeweld, M. and P. Alkemade, "LIS micro-data and national accounts macrodata comparison: Findings from wave i-wave viii”, LIS Technical Working Paper Series no. 7. Luxembourg Income Study, Luxembourg, 2014.

European Commission, Employment and Social Affairs developments in Europe 2013, Publications Office of the European Union, Luxembourg, 2014a.

European Commission, EU employment and social situation quality review: Towards $a$ better measurement of welfare and inequalities, Publications Office of the European Union, Luxembourg, 2014b.

Feldstein, M., "Underestimating the real growth of GDP, personal income, and productivity", Journal of Economic Perspectives, 31(2), 145-164, 2017.

Ferreira, F. H. G., N. Lustig, a nd D. Teles, "Appraising cross-national income inequality databases: An introduction", Journal of Economic Inequality, 13(4), 497526, 2015.

Fesseau, M. and M. Mattonetti, "Distributional measures across house- hold groups in a national accounts framework: Results from an experimental cross-country exercise on household income, consumption and saving", OECD Statistics Working Papers No. 2013/04, OECD, Paris, 2013.

Fesseau, M., F. Wolff, and M. Mattonetti, "A cross-country comparison of household income, consumption and wealth between micro sources and national accounts aggregates", OECD Statistics Working Papers No. 2013/03, OECD, Paris, 2013.

Fixler, D. and T. Jaditz, "An examination of the difference between the CPI and the price deflator", B L S Working Paper no. 361 Bureau of Labor Statistics, Washington DC, 2002.

Fixler, D., D. Johnson, A. Craig, and K. Furlong, A consistent data series to evaluate growth and inequality in the national accounts, Technical report, Bureau of Economic Analysis, Washington DC. 2016.

Gornick, J. M. Jäntti, Income Inequality: Economic Disparities and the Middle Class in Affluent Countries, Stanford University Press, Stanford, 2014.

Gordon, R., The Rise and Fall of American Growth: The US Standard of Living since the Civil War, Princeton University Press, Princeton, 2016. 
Groshen, E., B. Moyer, A. Aizcorbe, R. Bradley and D. Friedman, "How government statistics adjust for potential biases from quality change and new goods in an age of digital technologies: A view from the trenches", Journal of Economic Perspectives, 31(2), 187-210, 2017.

Immervoll, H. and L. Richardson, "Redistribution policy and inequality reduction in OECD countries what has changed in two decades?" OECD Social, Employment and Migration Working Papers no. 122, OECD, Paris, 2011.

Jenkins, S.P., “Accounting for Inequality Trends: Decomposition Analyses for the UK, 1971- 86”, Economica, 62, No. 245, 29-63, 1995.

Jenkins, S., A. Brandolini, J. Micklewright, and B. Nolan, The Great Recession and the Distribution of Household Income. Oxford University Press, Oxford, 2012.

Jorgenson, D. W., J.S. Landefeld, and P. Schreyer, Measuring Economic Sustainability and Progress, University of Chicago Press, Chicago, 2014.

Lequiller, F. and D. Blades, Understanding National Accounts, $2^{\text {nd }}$. Edition, OECD, Paris, 2006.

LIS, Micro data runs for multiple countries completed in September 2015.

Nolan, B., M. Roser, and S. Thewissen, "Models, regimes, and the evolution of middle incomes in OECD countries". LIS Working Paper Series no. 660. Luxembourg Income Study, Luxembourg, 2016.

OECD, OECD Framework for Statistics on the Distribution of Household Income, Consumption and Wealth. OECD, Paris, 2013.

OECD, Economic Surveys: Luxembourg. OECD, Paris, 2015.

Peichl, A., N. Pestel, and H. Schneider, "Does Size Matter? The Impact of Changes in Household Structure on Income Distribution in Germany", Review of Income and Wealth, 58(1), 118-141, 2012.

Pessoa, J. P. and J. Van Reenen, "Decoupling of wage growth and productivity growth? myth and reality", CEP Discussion Paper No 1246, London School of Economics, London, 2013.

Pinkovskiy, M. and X. Sala-i Martin, "Lights, Camera ... Income! Illuminating the National Accounts-Household Surveys Debate". The Quarterly Journal of Economics, (pp. qjw003), 2016.

Piketty, T., E. Saez, and G. Zucman, "Distributional National Accounts: Methods and Estimates for the United States", NBER Working Paper No. 22945, NBER, Washington DC, 2016.

Ravallion, M., "The Luxembourg Income Study", The Journal of Economic Inequality, 13(4), 527-547, 2015.

Ribarsky, J., C. Kang and E. Bolton, The drivers of differences between growth in GDP and household adjusted disposable income in OECD countries, OECD Statistics Working Papers 2016/06, OECD, Paris, 2016.

Smeeding, T. M. and D.H. Weinberg, "Toward a Uniform Definition of Household Income", Review of Income and Wealth, 47(1), 1-24, 2001.

Stiglitz, J., A. Sen, A., and J.-P. Fitoussi, Report of the Commission on the Measurement of Economic Performance and Social Progress, 2009.

Syverson, C., "Challenges to mismeasurement explanations for the US productivity slowdown”, Journal of Economic Perspectives, 31(2), 165-186, 2017.

Thewissen, S., L. Kenworthy, B. Nolan, M. Roser, and T. Smeeding, "Rising 
income inequality and living standards in OECD countries: How does the middle fare?", LIS Working Paper Series no. 656, Luxembourg Income Study, Luxembourg, 2015.

Thewissen, S., B, Nolan, and M. Roser, Incomes across the distribution database, https://ourworldindata.org/incomes-across-the-distribution, 2016.

Törmälehto, V.-M., "LIS and national accounts comparison”, LIS Technical Working Paper Series no. 2. Luxembourg Income Study, Luxembourg, 2011.

Zucman, G., The Hidden Wealth of Nations: The Scourge of Tax Havens. University of Chicago Press, Chicago, 2015. 


\section{Appendix 1: The Ordering of the Decomposition}

Table A1.1: Decomposing the GDP-median household income divergence in different orders

\begin{tabular}{|c|c|c|c|c|c|c|c|c|c|c|c|c|c|c|}
\hline & & \multicolumn{2}{|c|}{ (A) $\mathrm{CAGR} \%$} & \multirow{2}{*}{$\begin{array}{c}\text { Discre- } \\
\text { pancy } \\
(\mathrm{ppt}) \\
(3)\end{array}$} & \multicolumn{5}{|c|}{ (B) ppt contribution } & \multicolumn{5}{|c|}{ (C) $\%$ contribution } \\
\hline & & $\begin{array}{l}\text { GDP pc } \\
\text { DOB } \\
\text { (1) }\end{array}$ & $\begin{array}{l}\text { Median } \\
\text { equiv } \\
\text { (2) }\end{array}$ & & $\begin{array}{c}\text { National } \\
\text { income } \\
(4)\end{array}$ & $\begin{array}{l}\text { NA vs. } \\
\text { HS } \\
(5)\end{array}$ & $\begin{array}{l}\text { Inequa- } \\
\text { lity } \\
(6)\end{array}$ & $\begin{array}{c}\text { House- } \\
\text { hold size } \\
\text { (7) }\end{array}$ & $\begin{array}{l}\text { Prices } \\
\text { (8) }\end{array}$ & $\begin{array}{l}\text { National } \\
\text { income } \\
\text { (9) }\end{array}$ & $\begin{array}{l}\text { NA vs. } \\
\text { HS } \\
(10)\end{array}$ & $\begin{array}{l}\text { Inequa- } \\
\text { lity } \\
(11)\end{array}$ & $\begin{array}{l}\text { House- } \\
\text { hold size } \\
(12)\end{array}$ & $\begin{array}{c}\text { Prices } \\
\text { (13) }\end{array}$ \\
\hline Australia & $1981-2010$ & 1.83 & 1.21 & 0.62 & 0.08 & 0.01 & 0.16 & 0.24 & 0.13 & 14 & 1 & 25 & 39 & 21 \\
\hline Austria & $1994-2004$ & 2.13 & 0.92 & 1.21 & 0.02 & 0.54 & -0.13 & 0.28 & 0.50 & 2 & 45 & -11 & 23 & 41 \\
\hline Belgium & $1985-2000$ & 2.25 & 1.95 & 0.31 & -0.16 & -0.60 & 0.77 & 0.46 & -0.16 & -54 & -196 & 250 & 151 & -52 \\
\hline Canada & $1981-2010$ & 1.32 & 0.73 & 0.59 & -0.05 & 0.22 & 0.04 & 0.24 & 0.14 & -9 & 37 & 7 & 40 & 24 \\
\hline Czech Rep & $1992-2010$ & 2.65 & 2.85 & -0.20 & 0.41 & -1.25 & 0.17 & 0.25 & 0.22 & -210 & 639 & -88 & -130 & -110 \\
\hline Denmark & $1987-2010$ & 1.20 & 0.86 & 0.34 & -0.15 & 0.36 & 0.03 & 0.08 & 0.02 & -45 & 105 & 10 & 23 & 6 \\
\hline Estonia & $2000-2010$ & 3.62 & 6.14 & -2.52 & 0.16 & -0.80 & -0.68 & 0.24 & -1.44 & -6 & 32 & 27 & -10 & 57 \\
\hline Finland & $1987-2010$ & 1.83 & 1.42 & 0.41 & -0.08 & -0.01 & 0.25 & 0.28 & -0.03 & -19 & -3 & 62 & 68 & -7 \\
\hline France & $1978-2010$ & 1.45 & 0.85 & 0.59 & -0.05 & 0.18 & -0.14 & 0.42 & 0.18 & -9 & 31 & -24 & 72 & 31 \\
\hline Germany & $1984-2010$ & 1.64 & 0.55 & 1.09 & -0.02 & 0.56 & 0.06 & 0.28 & 0.21 & -2 & 51 & 6 & 26 & 19 \\
\hline Greece & $1995-2010$ & 2.06 & 2.00 & 0.06 & 0.30 & -0.51 & -0.25 & 0.32 & 0.19 & 535 & -898 & -445 & 573 & 334 \\
\hline Hungary & $1991-2012$ & 1.92 & -0.22 & 2.14 & 0.17 & 0.96 & -0.06 & 0.47 & 0.61 & 8 & 45 & -3 & 22 & 29 \\
\hline Iceland & $2004-2010$ & 0.61 & -0.18 & 0.80 & 2.19 & -1.78 & -0.61 & 0.36 & 0.64 & 275 & -224 & -76 & 45 & 80 \\
\hline Ireland & $1987-2010$ & 4.17 & 3.19 & 0.99 & 0.47 & -0.05 & -0.12 & 0.54 & 0.15 & 47 & -5 & -12 & 55 & 15 \\
\hline Israel & $1986-2010$ & 2.14 & 1.59 & 0.56 & -0.20 & 0.30 & 0.14 & 0.20 & 0.11 & -35 & 53 & 26 & 37 & 20 \\
\hline Italy & $1986-2010$ & 1.06 & 0.83 & 0.24 & -0.01 & 0.07 & 0.01 & 0.44 & -0.26 & -5 & 27 & 3 & 182 & -108 \\
\hline Luxembourg & $1985-2010$ & 3.23 & 2.81 & 0.42 & 0.76 & -0.25 & 0.11 & 0.17 & -0.36 & 179 & -59 & 25 & 40 & -85 \\
\hline Netherlands & $1993-2010$ & 1.89 & 1.34 & 0.56 & -0.04 & 0.38 & -0.16 & 0.44 & -0.06 & -8 & 68 & -28 & 79 & -11 \\
\hline Norway & $1979-2010$ & 2.06 & 2.38 & -0.32 & -0.15 & 0.20 & -0.11 & 0.33 & -0.60 & 46 & -63 & 35 & -102 & 183 \\
\hline Poland & $1992-2010$ & 4.46 & 1.56 & 2.90 & -0.13 & 2.02 & 0.24 & 0.27 & 0.50 & -4 & 70 & 8 & 9 & 17 \\
\hline Slovak Rep & $1992-2010$ & 4.36 & 2.23 & 2.13 & 0.16 & -0.16 & 0.20 & 0.18 & 1.74 & 8 & -7 & 9 & 9 & 81 \\
\hline Slovenia & $1997-2010$ & 2.77 & 1.96 & 0.82 & 0.11 & -0.28 & -0.05 & 0.63 & 0.41 & 14 & -35 & -6 & 76 & 50 \\
\hline Spain & $1980-2010$ & 1.90 & 1.71 & 0.20 & 0.02 & -0.16 & -0.15 & 0.66 & -0.17 & 8 & -79 & -77 & 334 & -86 \\
\hline Sweden & $1981-2005$ & 1.98 & 1.89 & 0.09 & -0.08 & 0.30 & 0.21 & -0.21 & -0.13 & -82 & 326 & 230 & -228 & -147 \\
\hline Switzerland & 2000-2004 & 0.40 & 0.59 & -0.19 & 0.07 & 0.21 & -0.72 & -0.02 & 0.26 & -38 & -111 & 375 & 10 & -137 \\
\hline UK & $1979-2010$ & 1.94 & 1.73 & 0.21 & -0.05 & 0.01 & 0.22 & 0.41 & -0.38 & -23 & 3 & 105 & 197 & -182 \\
\hline US & $1979-2013$ & 1.60 & 0.32 & 1.27 & -0.09 & 0.32 & 0.28 & 0.17 & 0.59 & -7 & 25 & 22 & 13 & 47 \\
\hline Average & & 2.17 & 1.60 & 0.57 & 0.14 & 0.03 & -0.01 & 0.30 & 0.11 & 24 & 5 & -2 & 53 & 20 \\
\hline Standard dev & & 1.04 & 1.26 & 0.97 & 0.47 & 0.69 & 0.31 & 0.19 & 0.54 & 131 & 238 & 137 & 145 & 105 \\
\hline
\end{tabular}




\section{Appendix 2: Decomposing the GDP-median household income divergence for different time-periods for six countries}

The results in Section 8 on the decomposition of the GDP per capita-median income divergence for five large countries by sub-period were presented in terms of percentage point contributions. To provide a comprehensive picture for these countries, this appendix sets out the full decomposition results including percentage contributions and underlying annual growth rates.

Table A2.1: Decomposing the GDP-median household income divergence for different time-periods: USA

\begin{tabular}{|c|c|c|c|c|c|c|c|c|c|c|}
\hline Years & $\begin{array}{l}1979- \\
2013 \\
\end{array}$ & $\begin{array}{c}1979- \\
1986 \\
\end{array}$ & $\begin{array}{l}1986- \\
1991 \\
\end{array}$ & $\begin{array}{l}1991- \\
1994 \\
\end{array}$ & $\begin{array}{l}1994- \\
1997 \\
\end{array}$ & $\begin{array}{l}1997- \\
2000 \\
\end{array}$ & $\begin{array}{l}2000- \\
2004\end{array}$ & $\begin{array}{l}2004- \\
2007 \\
\end{array}$ & $\begin{array}{l}2007- \\
2010 \\
\end{array}$ & $\begin{array}{l}2010- \\
2013 \\
\end{array}$ \\
\hline (A) Divergence & 1.27 & 1.72 & 1.52 & 2.28 & 0.73 & 0.87 & 1.17 & 1.17 & -0.03 & 1.31 \\
\hline \multicolumn{11}{|l|}{$\begin{array}{l}\text { (B) ppt } \\
\text { contribution }\end{array}$} \\
\hline Prices & 0.60 & 0.75 & 1.02 & 0.60 & 0.82 & 0.75 & 0.20 & 0.17 & 0.37 & 0.38 \\
\hline National income & -0.09 & 0.12 & -0.08 & 0.21 & -0.58 & -0.40 & 0.13 & 0.02 & -0.10 & -0.50 \\
\hline NA vs HS & 0.32 & 0.06 & 0.13 & 0.01 & 0.18 & 0.77 & 0.79 & 0.51 & -0.06 & 0.80 \\
\hline Household size & 0.14 & 0.39 & 0.21 & -0.15 & 0.24 & -0.03 & -0.01 & 0.23 & -0.01 & 0.04 \\
\hline Inequality & 0.31 & 0.40 & 0.23 & 1.60 & 0.07 & -0.21 & 0.06 & 0.25 & -0.23 & 0.60 \\
\hline \multicolumn{11}{|l|}{ (C) $\%$ contribution } \\
\hline Prices & 47 & 43 & 67 & 26 & 112 & 86 & 17 & 15 & -1390 & 29 \\
\hline National income & -7 & 7 & -5 & 9 & -79 & -47 & 11 & 1 & 368 & -38 \\
\hline NA vs HS & 25 & 3 & 9 & 0 & 25 & 89 & 67 & 44 & 228 & 61 \\
\hline Household size & 11 & 23 & 14 & -7 & 33 & -4 & -1 & 19 & 47 & 3 \\
\hline Inequality & 24 & 23 & 15 & 70 & 9 & -25 & 5 & 21 & 847 & 46 \\
\hline \multicolumn{11}{|c|}{ (D) Basic trends (CAGR \%) } \\
\hline GDP pc DOB & 1.60 & 1.88 & 1.56 & 2.10 & 2.44 & 3.22 & 1.39 & 1.63 & -1.08 & 1.00 \\
\hline GDP pc CPI & 1.00 & 1.13 & 0.54 & 1.50 & 1.63 & 2.48 & 1.19 & 1.46 & -1.45 & 0.62 \\
\hline GNI pc CPI & 1.09 & 1.02 & 0.62 & 1.29 & 2.20 & 2.88 & 1.06 & 1.44 & -1.35 & 1.12 \\
\hline Mean per capita & 0.77 & 0.96 & 0.49 & 1.28 & 2.02 & 2.11 & 0.27 & 0.93 & -1.29 & 0.33 \\
\hline Mean equivalised & 0.63 & 0.56 & 0.28 & 1.43 & 1.78 & 2.14 & 0.28 & 0.70 & -1.28 & 0.29 \\
\hline Median equivalised & 0.32 & 0.16 & 0.05 & -0.18 & 1.72 & 2.36 & 0.22 & 0.46 & -1.06 & -0.32 \\
\hline
\end{tabular}


Table A2.2: Decomposing the GDP-median household income divergence for different time-periods: Australia

\begin{tabular}{|c|c|c|c|c|c|c|c|c|}
\hline Years & $\begin{array}{l}1981- \\
2010\end{array}$ & $\begin{array}{c}1981- \\
1985\end{array}$ & $\begin{array}{c}1985- \\
1989\end{array}$ & $\begin{array}{c}1989- \\
1995\end{array}$ & $\begin{array}{c}1995- \\
2001\end{array}$ & $\begin{array}{l}2001- \\
2003\end{array}$ & $\begin{array}{c}2003- \\
2008\end{array}$ & $\begin{array}{c}2008- \\
2010\end{array}$ \\
\hline (A) Divergence & 0.62 & 1.53 & 2.09 & 2.88 & 0.70 & 1.90 & -4.81 & 0.63 \\
\hline \multicolumn{9}{|l|}{ (B) ppt contribution } \\
\hline Prices & 0.13 & 0.69 & 0.65 & 1.35 & 0.18 & -0.34 & -1.57 & -1.20 \\
\hline National income & 0.08 & -0.03 & 0.46 & 0.03 & -0.14 & 0.07 & 0.14 & 0.28 \\
\hline NA vs HS & 0.01 & -0.04 & 0.52 & 1.55 & 0.22 & 1.12 & -3.66 & 1.48 \\
\hline Household size & 0.16 & 0.80 & -0.09 & -0.12 & 0.39 & 0.66 & -0.13 & -0.30 \\
\hline Inequality & 0.24 & 0.10 & 0.55 & 0.07 & 0.05 & 0.39 & 0.41 & 0.38 \\
\hline \multicolumn{9}{|l|}{ (C) $\%$ contribution } \\
\hline Prices & 21 & 45 & 31 & 47 & 25 & -18 & 33 & -189 \\
\hline National income & 14 & -2 & 22 & 1 & -21 & 4 & -3 & 44 \\
\hline NA vs HS & 1 & -2 & 25 & 54 & 32 & 59 & 76 & 234 \\
\hline Household size & 26 & 52 & -5 & -4 & 56 & 35 & 3 & -47 \\
\hline Inequality & 38 & 7 & 26 & 2 & 7 & 20 & -8 & 59 \\
\hline \multicolumn{9}{|c|}{ (D) Basic trends (CAGR \%) } \\
\hline GDP pc DOB & 1.83 & 1.45 & 2.32 & 1.47 & 2.66 & 2.44 & 1.55 & 0.31 \\
\hline GDP pc CPI & 1.70 & 0.76 & 1.67 & 0.11 & 2.49 & 2.78 & 3.12 & 1.51 \\
\hline GNI pc CPI & 1.62 & 0.78 & 1.21 & 0.08 & 2.63 & 2.71 & 2.99 & 1.23 \\
\hline Mean per capita & 1.61 & 0.82 & 0.69 & -1.46 & 2.41 & 1.59 & 6.65 & -0.25 \\
\hline Mean equivalised & 1.45 & 0.02 & 0.78 & -1.34 & 2.02 & 0.93 & 6.77 & 0.05 \\
\hline Median equivalised & 1.21 & -0.08 & 0.23 & -1.41 & 1.97 & 0.54 & 6.36 & -0.32 \\
\hline
\end{tabular}


Table A2.3: Decomposing the GDP-median household income divergence for different time-periods: Canada

\begin{tabular}{|c|c|c|c|c|c|c|c|c|c|c|}
\hline Years & $\begin{array}{c}1981- \\
2010 \\
\end{array}$ & $\begin{array}{l}1981- \\
1987 \\
\end{array}$ & $\begin{array}{c}1987- \\
1991 \\
\end{array}$ & $\begin{array}{c}1991- \\
1994 \\
\end{array}$ & $\begin{array}{c}1994- \\
1997 \\
\end{array}$ & $\begin{array}{l}1997- \\
1998 \\
\end{array}$ & $\begin{array}{l}1998- \\
2000 \\
\end{array}$ & $\begin{array}{c}2000- \\
2004 \\
\end{array}$ & $\begin{array}{c}2004- \\
2007 \\
\end{array}$ & $\begin{array}{c}2007- \\
2010 \\
\end{array}$ \\
\hline (A) Divergence & 0.59 & 1.11 & -0.04 & 1.49 & 1.89 & 1.30 & 4.61 & -0.28 & -1.24 & -1.70 \\
\hline \multicolumn{11}{|l|}{$\begin{array}{l}\text { (B) ppt } \\
\text { contribution }\end{array}$} \\
\hline Prices & 0.14 & 0.68 & 0.90 & -0.25 & 0.07 & 1.23 & -0.85 & -0.01 & -0.93 & 0.05 \\
\hline National income & -0.05 & -0.04 & 0.06 & 0.09 & -0.17 & 0.27 & -0.40 & -0.12 & -0.24 & 0.16 \\
\hline NA vs HS & 0.22 & 0.43 & -1.33 & 1.04 & 1.84 & -1.15 & 4.69 & -0.42 & -0.43 & -1.53 \\
\hline Household size & 0.11 & -0.10 & 0.16 & 0.60 & 0.16 & -1.12 & 0.10 & 0.29 & 0.24 & -0.04 \\
\hline Inequality & 0.17 & 0.14 & 0.18 & 0.00 & -0.01 & 2.07 & 1.07 & -0.01 & 0.12 & -0.33 \\
\hline \multicolumn{11}{|l|}{ (C) $\%$ contribution } \\
\hline Prices & 24 & 62 & -2359 & -17 & 4 & 95 & -18 & 4 & 75 & -3 \\
\hline National income & -9 & -4 & -151 & 6 & -9 & 21 & -9 & 44 & 20 & -9 \\
\hline NA vs HS & 37 & 39 & 3479 & 70 & 97 & -89 & 102 & 149 & 34 & 90 \\
\hline Household size & 18 & -9 & -409 & 40 & 8 & -86 & 2 & -102 & -19 & 3 \\
\hline Inequality & 29 & 13 & -461 & 0 & 0 & 159 & 23 & 5 & -9 & 19 \\
\hline \multicolumn{11}{|c|}{ (D) Basic trends (CAGR \%) } \\
\hline GDP pc DOB & 1.32 & 1.55 & -0.22 & 1.51 & 1.84 & 3.28 & 4.15 & 1.37 & 1.56 & -0.61 \\
\hline GDP pc CPI & 1.17 & 0.87 & -1.12 & 1.76 & 1.77 & 2.05 & 5.00 & 1.38 & 2.49 & -0.66 \\
\hline GNI pc CPI & 1.22 & 0.91 & -1.18 & 1.67 & 1.94 & 1.78 & 5.40 & 1.50 & 2.73 & -0.81 \\
\hline Mean per capita & 1.01 & 0.48 & 0.15 & 0.63 & 0.10 & 2.93 & 0.71 & 1.92 & 3.16 & 0.72 \\
\hline Mean equivalised & 0.90 & 0.58 & -0.01 & 0.03 & -0.06 & 4.05 & 0.61 & 1.63 & 2.92 & 0.76 \\
\hline Median equivalised & 0.73 & 0.44 & -0.18 & 0.02 & -0.05 & 1.98 & -0.47 & 1.65 & 2.80 & 1.09 \\
\hline
\end{tabular}


Table A2.4: Decomposing the GDP-median household income divergence for different time-periods: France

\begin{tabular}{|c|c|c|c|c|c|c|c|}
\hline Years & $\begin{array}{c}1978- \\
2010\end{array}$ & $\begin{array}{c}1978- \\
1984 \\
\end{array}$ & $\begin{array}{c}1984- \\
1989 \\
\end{array}$ & $\begin{array}{c}1989- \\
1994\end{array}$ & $\begin{array}{l}1994- \\
2000\end{array}$ & $\begin{array}{l}2000- \\
2005\end{array}$ & $\begin{array}{c}2005- \\
2010\end{array}$ \\
\hline (A) Divergence & 0.59 & 2.12 & 1.64 & -0.96 & 2.23 & 0.09 & -2.21 \\
\hline \multicolumn{8}{|l|}{ (B) ppt contribution } \\
\hline Prices & 0.19 & 0.62 & -0.33 & 0.55 & 0.29 & 0.00 & -0.13 \\
\hline National income & -0.05 & 0.13 & -0.19 & -0.01 & -0.23 & 0.02 & -0.06 \\
\hline NA vs HS & 0.18 & 0.74 & 2.84 & -2.70 & 2.26 & 0.15 & -2.76 \\
\hline Household size & 0.34 & 0.39 & 0.35 & 0.45 & 0.15 & 0.16 & 0.60 \\
\hline Inequality & -0.06 & 0.23 & -1.03 & 0.76 & -0.24 & -0.25 & 0.14 \\
\hline \multicolumn{8}{|l|}{ (C) $\%$ contribution } \\
\hline Prices & 31 & 29 & -20 & -57 & 13 & -1 & 6 \\
\hline National income & -9 & 6 & -12 & 1 & -10 & 27 & 3 \\
\hline NA vs HS & 31 & 35 & 173 & 282 & 101 & 172 & 125 \\
\hline Household size & 58 & 19 & 21 & -47 & 7 & 180 & -27 \\
\hline Inequality & -11 & 11 & -63 & -79 & -11 & -278 & -6 \\
\hline \multicolumn{8}{|c|}{ (D) Basic trends (CAGR \%) } \\
\hline GDP pc DOB & 1.45 & 1.40 & 2.60 & 1.01 & 2.36 & 0.94 & 0.21 \\
\hline GDP pc CPI & 1.26 & 0.78 & 2.94 & 0.46 & 2.07 & 0.94 & 0.34 \\
\hline GNI pc CPI & 1.32 & 0.65 & 3.13 & 0.47 & 2.30 & 0.92 & 0.40 \\
\hline Mean per capita & 1.13 & -0.10 & 0.29 & 3.18 & 0.04 & 0.77 & 3.15 \\
\hline Mean equivalised & 0.79 & -0.49 & -0.06 & 2.73 & -0.11 & 0.61 & 2.56 \\
\hline Median equivalised & 0.85 & -0.72 & 0.97 & 1.97 & 0.13 & 0.85 & 2.42 \\
\hline
\end{tabular}


Table A2.5: Decomposing the GDP-median household income divergence for different time-periods: Germany

\begin{tabular}{|c|c|c|c|c|c|c|c|}
\hline Years & $\begin{array}{c}1984- \\
2010\end{array}$ & $\begin{array}{c}1984- \\
1989 \\
\end{array}$ & $\begin{array}{c}1989- \\
1994 \\
\end{array}$ & $\begin{array}{c}1994- \\
2000\end{array}$ & $\begin{array}{c}2000- \\
2004\end{array}$ & $\begin{array}{c}2004- \\
2007 \\
\end{array}$ & $\begin{array}{c}2007- \\
2010 \\
\end{array}$ \\
\hline (A) Divergence & 1.09 & 0.10 & 2.99 & 0.49 & 0.46 & 3.28 & -0.59 \\
\hline \multicolumn{8}{|l|}{ (B) ppt contribution } \\
\hline Prices & 0.21 & -0.96 & 0.18 & 0.79 & 0.29 & 0.94 & 0.22 \\
\hline National income & -0.02 & -0.05 & 0.31 & 0.13 & -0.34 & -0.26 & -0.16 \\
\hline NA vs HS & 0.55 & 0.54 & 2.10 & -0.66 & -0.24 & 1.92 & 0.11 \\
\hline Household size & 0.25 & 0.32 & 0.32 & 0.20 & 0.32 & 0.32 & -0.01 \\
\hline Inequality & 0.09 & 0.25 & 0.07 & 0.02 & 0.43 & 0.35 & -0.74 \\
\hline \multicolumn{8}{|l|}{ (C) $\%$ contribution } \\
\hline Prices & 20 & -1004 & 6 & 162 & 63 & 29 & -38 \\
\hline National income & -2 & -52 & 10 & 26 & -75 & -8 & 28 \\
\hline NA vs HS & 51 & 559 & 70 & -135 & -52 & 59 & -19 \\
\hline Household size & 23 & 337 & 11 & 42 & 69 & 10 & 2 \\
\hline Inequality & 8 & 259 & 2 & 5 & 95 & 11 & 127 \\
\hline \multicolumn{8}{|c|}{ (D) Basic trends (CAGR \%) } \\
\hline GDP pc DOB & 1.64 & 2.49 & 2.04 & 1.73 & 0.44 & 2.65 & -0.04 \\
\hline GDP pc CPI & 1.42 & 3.45 & 1.87 & 0.94 & 0.15 & 1.71 & -0.26 \\
\hline GNI pc CPI & 1.44 & 3.50 & 1.56 & 0.81 & 0.49 & 1.97 & -0.10 \\
\hline Mean per capita & 0.89 & 2.96 & -0.55 & 1.47 & 0.73 & 0.04 & -0.21 \\
\hline Mean equivalised & 0.63 & 2.64 & -0.87 & 1.27 & 0.42 & -0.28 & -0.19 \\
\hline Median equivalised & 0.55 & 2.39 & -0.95 & 1.24 & -0.02 & -0.63 & 0.55 \\
\hline
\end{tabular}

